\title{
Inhibitors of Mammalian Aquaporin Water Channels
}

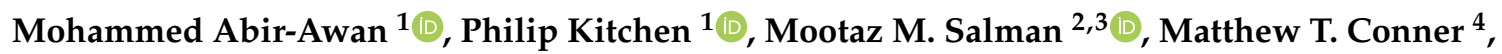 \\ Alex C. Conner ${ }^{5}$ and Roslyn M. Bill ${ }^{1, * \mathbb{D}}$ \\ 1 School of Life \& Health Sciences, Aston University, Aston Triangle, Birmingham B4 7ET, UK; \\ abirawam@aston.ac.uk (M.A.-A.); p.kitchen1@aston.ac.uk (P.K.) \\ 2 Department of Cell Biology, Harvard Medical School, 200 Longwood Avenue, Boston, MA 02115, USA; \\ Mootaz.Salman@childrens.harvard.edu \\ 3 Program in Cellular and Molecular Medicine, Boston Children's Hospital, 200 Longwood Avenue, \\ Boston, MA 02115, USA \\ 4 Research Institute of Health Sciences, School of Sciences, University of Wolverhampton, \\ Wolverhampton WV1 1LY, UK; m.conner@wlv.ac.uk \\ 5 Institute of Clinical Sciences, College of Medical and Dental Sciences, University of Birmingham, Edgbaston, \\ Birmingham B15 2TT, UK; a.c.conner@bham.ac.uk \\ * Correspondence: r.m.bill@aston.ac.uk; Tel.: +44-121-204-4274
}

Received: 28 February 2019; Accepted: 26 March 2019; Published: 29 March 2019

\begin{abstract}
Aquaporins (AQPs) are water channel proteins that are essential to life, being expressed in all kingdoms. In humans, there are $13 \mathrm{AQPs}$, at least one of which is found in every organ system. The structural biology of the AQP family is well-established and many functions for AQPs have been reported in health and disease. AQP expression is linked to numerous pathologies including tumor metastasis, fluid dysregulation, and traumatic injury. The targeted modulation of AQPs therefore presents an opportunity to develop novel treatments for diverse conditions. Various techniques such as video microscopy, light scattering and fluorescence quenching have been used to test putative AQP inhibitors in both AQP-expressing mammalian cells and heterologous expression systems. The inherent variability within these methods has caused discrepancy and many molecules that are inhibitory in one experimental system (such as tetraethylammonium, acetazolamide, and anti-epileptic drugs) have no activity in others. Some heavy metal ions (that would not be suitable for therapeutic use) and the compound, TGN-020, have been shown to inhibit some AQPs. Clinical trials for neuromyelitis optica treatments using anti-AQP4 IgG are in progress. However, these antibodies have no effect on water transport. More research to standardize high-throughput assays is required to identify AQP modulators for which there is an urgent and unmet clinical need.
\end{abstract}

Keywords: aquaporin; $\mathrm{AQP}$ inhibitors; $\mathrm{AQP}$ modulators; functional assays; $\mathrm{AQP}$ expression; $\mathrm{AQPs}$ in disease; $\mathrm{AQP}$ structure; TGN-020; heavy metals; small molecule inhibitors

\section{Aquaporin Structure}

Aquaporins (AQPs) are transmembrane proteins that facilitate the bidirectional transport of water across cell membranes; water flows through AQP pores following an osmotic gradient to support water homeostasis [1-3]. A subset of the AQP family, the aquaglyceroporins, also allows the transport of glycerol and other small neutral solutes such as urea and ammonia [4-7]. These include AQP3, AQP7, AQP9, and AQP10. Currently, there are 13 known mammalian AQPs, each with a structure comprising six membrane-spanning helices (Table 1). The amino- and carboxy-termini of APQs are both intracellular $[3,8]$. Two opposing, shorter helices do not span the entire membrane (Figure 1), but form the pore itself $[3,9,10]$. These half helices contain the family's signature triplet amino acid NPA (Asn-Pro-Ala) motif, as seen in Figure 1a $[8,11]$. The residues in this motif orient water molecules 
to prevent protons from entering the channel, as well as acting as the hydrogen bond donors and acceptors that facilitate the passage of water molecules [3]. The narrowest segment of the AQP channel is within the transmembrane region of the pore. For AQP1, it is $2.8 \AA$ in diameter, which is similar to the size of a single water molecule. This feature means water molecules pass through AQPs in single file. A high resolution $(0.88 \AA)$ X-ray crystal structure of a yeast AQP, Aqy1, revealed that the selectivity filter within the pore contains four positions for water molecules and that it is not possible for these positions to be occupied simultaneously. Instead they travel in a pairwise fashion, filling two of these positions at a time [12].

AQPs form homotetramers within the plasma membrane. Each homotetramer consists of four water channels (Figure 1b) [13,14]. Each water channel is functionally independent. It has been shown that channel pore size can sometimes be variable. When the residues responsible for the widening and narrowing of the channel entrance were in an 'open' state, molecular dynamics simulations suggested that the channel entrance was wider in monomeric than tetrameric AQP5, although it is not clear how this might affect water permeability [15]. For AQP4, functional and mutagenesis studies suggested that non-tetrameric AQPs have the same water permeability as those found in tetramers [16]. Although the reason AQPs form tetramers is not fully understood [17,18], it has been shown that non-tetrameric forms of AQP4 do not undergo hypotonicity-induced intracellular trafficking [16].

A controversial topic in AQP biology, related to their homotetrameric nature, has been their conduction of ions and whether this takes place. AQP tetramers contain a potential fifth central pore as shown in Figure 1b, reminiscent of cation channels such as Kir 2.1 [19]. The use of forskolin has been reported to induce cationic permeability in AQP1 [20], however, follow-up experiments by different groups failed to replicate this [21]. Direct binding of cGMP to AQP1 expressed in Xenopus oocytes has been shown to cause an ionic current after cGMP binding to a predicted site found in the AQP1 carboxyl tail [22]. The central pore of AQP1 was also found to be gas permeable using molecular dynamics simulations. However, conduction of $\mathrm{O}_{2}$ and $\mathrm{CO}_{2}$ through AQP1 may only be physiologically relevant in membranes of low gas permeability where there are high concentrations of AQPs [23]. Recently, a review of evidence for the gas permeability of AQPs suggested that that it may be functionally important in some cells, but not in others [24]. Less controversially, AQP6 is permeable to nitrate and chloride ions [25-28], and AQP8 is permeable to ammonia [29-31]. In a high resolution X-ray crystal structure of human AQP5, however, a lipid molecule co-crystallized with the protein, occluding the fifth central pore, suggesting another possible role [32].
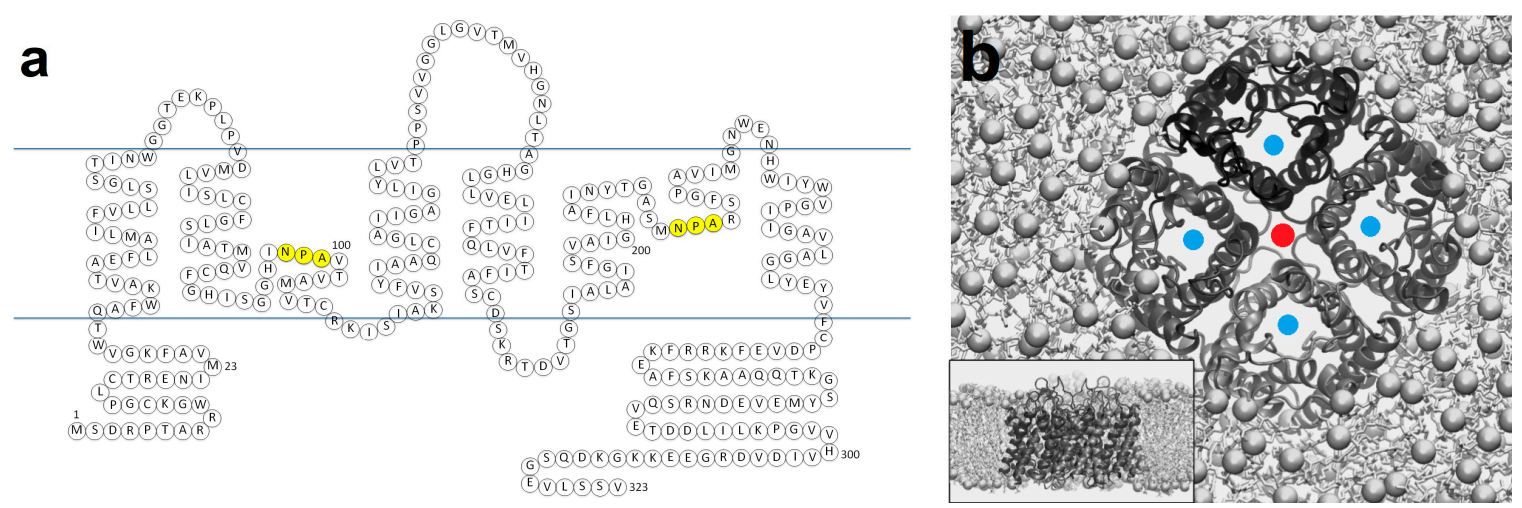

Figure 1. Aquaporin structure: (a) primary sequence of Aquaporin 4 (AQP4), the water channel with the highest recorded water permeability (see Table 1), highlighting the NPA (Asn-Pro-Ala) residues in yellow; (b) tertiary structure of the AQP4 homotetramer showing four water pores (marked with a blue dot) and the 'fifth pore' produced by formation of the tetramer (marked with a red dot). Adapted from an image originally published in [33]. 
Table 1. A summary of AQPs 0-12 showing the information available on their structure, permeability, location within the body and pathophysiology. The osmotic water permeability coefficient $\left(\mathrm{P}_{\mathrm{f}}\right)$ relates the magnitude of bulk water flow across a membrane in response to hydrostatic or osmotic pressure gradients to the magnitude of the driving pressure gradient. It depends on both the permeability of individual water channels and the density of channels in the membrane. $P_{\text {gly }}$ is the glycerol permeability coefficient. The single channel osmotic water permeability coefficient $\left(\mathrm{p}_{\mathrm{f}}\right)$ is also given where available.

\begin{tabular}{|c|c|c|c|c|c|}
\hline AQP & $\begin{array}{l}\text { Structural } \\
\text { Information } \\
\text { Available }\end{array}$ & $\begin{array}{l}\text { Water Permeability } \\
\text { (Glycerol Permeability Is } \\
\text { Also Given for } \\
\text { Aquaglyceroporins) }\end{array}$ & $\begin{array}{l}\text { Main Locations in } \\
\text { Humans }\end{array}$ & Disease States & References \\
\hline AQP0 & $\begin{array}{l}\text { PDB ref: } 1 Y M G \\
\text { Resolution: } 2.2 \AA \\
\text { Species: Bos taurus } \\
\text { Method: X-ray } \\
\text { diffraction } \\
\text { Amino acids: } 263\end{array}$ & $\begin{array}{l}\text { Xenopus oocytes- } \\
5 \mathrm{ng} \text { cRNA } \\
\mathrm{P}_{\mathrm{f}}: 1.3 \times 10^{-3} \mathrm{~cm} / \mathrm{s} \\
(\text { control with no AQP } \\
\left.0.67 \times 10^{-3} \mathrm{~cm} / \mathrm{s}\right) \\
\mathrm{p}_{\mathrm{f}}: 0.25 \times 10^{-14} \mathrm{~cm}^{3} / \mathrm{s} \\
\text { - single channel } \\
\text { permeability }\end{array}$ & Lens & $\begin{array}{l}\text { Mutations in the } \\
\text { gene for AQP0 } \\
\text { often result in } \\
\text { bilateral cataracts }\end{array}$ & {$[7,34-36]$} \\
\hline AQP1 & $\begin{array}{l}\text { PDB ref: 1FQY } \\
\text { Resolution: } 3.8 \AA \\
\text { Species: Homo sapiens } \\
\text { Method: Electron } \\
\text { crystallography } \\
\text { Amino acids: } 269\end{array}$ & $\begin{array}{l}\text { Xenopus oocytes- } \\
5 \mathrm{ng} \text { cRNA } \\
\mathrm{P}_{\mathrm{f}}: 19 \times 10^{-3} \mathrm{~cm} / \mathrm{s} \text { (control } \\
0.67 \times 10^{-3} \mathrm{~cm} / \mathrm{s} \text { ) } \\
\mathrm{p}_{\mathrm{f}}: 6.0 \times 10^{-14} \mathrm{~cm}^{3} / \mathrm{s} \\
\text { - single channel } \\
\text { permeability }\end{array}$ & $\begin{array}{l}\text { Erythrocytes } \\
\text { Choroid plexus } \\
\text { Eye epithelium } \\
\text { Corneal epithelium } \\
\text { Bile duct } \\
\text { Capillaries } \\
\text { Nephron } \\
\text { Airways } \\
\text { Skeletal muscle }\end{array}$ & $\begin{array}{l}\text { Deficiency causes } \\
\text { inability to } \\
\text { concentrate urine } \\
\text { Tumors with AQP1 } \\
\text { have increased } \\
\text { metastases and } \\
\text { invasiveness } \\
\text { Altered pain } \\
\text { sensation }\end{array}$ & {$[3,7,37-40]$} \\
\hline AQP2 & $\begin{array}{l}\text { PDB ref: } 4 \text { NEF } \\
\text { Resolution: } 2.75 \AA \\
\text { Species: Homo sapiens } \\
\text { Method: X-ray } \\
\text { diffraction } \\
\text { Amino acids: } 242\end{array}$ & $\begin{array}{l}\text { Xenopus oocytes- } \\
5 \mathrm{ng} \text { cRNA } \\
\mathrm{P}_{\mathrm{f}}: 10 \times 10^{-3} \mathrm{~cm} / \mathrm{s} \text { (control } \\
0.67 \times 10^{-3} \mathrm{~cm} / \mathrm{s} \text { ) } \\
\mathrm{p}_{\mathrm{f}}: 3.3 \times 10^{-14} \mathrm{~cm}^{3} / \mathrm{s} \\
\text { 一 single channel } \\
\text { permeability }\end{array}$ & $\begin{array}{l}\text { Collecting duct } \\
\text { cells }\end{array}$ & $\begin{array}{l}\text { Deficiency causes } \\
\text { diabetes insipidus }\end{array}$ & {$[7,39,41,42]$} \\
\hline AQP3 & $\begin{array}{l}\text { No structural data } \\
\text { available } \\
\text { UniProtKB-O92482 } \\
\text { Species: Homo sapiens } \\
\text { Amino acids: } 292\end{array}$ & $\begin{array}{l}\text { Xenopus oocytes- } \\
5 \text { ng cRNA } \\
\mathrm{P}_{\mathrm{f}}: 8.0 \times 10^{-3} \mathrm{~cm} / \mathrm{s} \\
\left(\text { control } 0.67 \times 10^{\mathrm{c} 3} \mathrm{~cm} / \mathrm{s}\right) \\
\mathrm{p}_{\mathrm{f}}: 2.1 \times 10^{-14} \mathrm{~cm}^{3} / \mathrm{s} \\
\text { - single channel } \\
\text { permeability } \\
\mathrm{P}_{\text {gly }}: 23 \times 10^{-6} \mathrm{~cm} / \mathrm{s}\end{array}$ & $\begin{array}{l}\text { Epidermis } \\
\text { Collecting duct } \\
\text { cells } \\
\text { Erythrocytes }\end{array}$ & $\begin{array}{l}\text { Skin dehydration } \\
\text { Psoriasis } \\
\text { Tumor } \\
\text { invasiveness and } \\
\text { metastases }\end{array}$ & {$[7,43-45]$} \\
\hline AQP4 & $\begin{array}{l}\text { PDB ref: 3GD8 } \\
\text { Resolution: } 1.8 \text { A } \\
\text { Species: Homo sapiens } \\
\text { Method: X-ray } \\
\text { diffraction } \\
\text { Amino acids: } 223\end{array}$ & $\begin{array}{l}\text { Xenopus oocytes- } \\
5 \mathrm{ng} \text { cRNA } \\
\mathrm{P}_{\mathrm{f}}: 29 \times 10^{-3} \mathrm{~cm} / \mathrm{s} \text { (control } \\
0.67 \times 10^{-3} \mathrm{~cm} / \mathrm{s} \text { ) } \\
\text { p }_{\mathrm{f}}: 24 \times 10^{-14} \mathrm{~cm}^{3} / \mathrm{s} \\
\text { 一 single channel } \\
\text { permeability }\end{array}$ & $\begin{array}{l}\text { Astrocytes } \\
\text { Parietal cells } \\
\text { Collecting duct } \\
\text { cells } \\
\text { Retina }\end{array}$ & $\begin{array}{l}\text { Cytotoxic edema } \\
\text { Vasogenic edema } \\
\text { Neuromyelitis } \\
\text { optica }\end{array}$ & {$[7,44,46]$} \\
\hline AQP5 & $\begin{array}{l}\text { PDB ref: 3D9S } \\
\text { Resolution: } 2 \AA \\
\text { Species: Homo sapiens } \\
\text { Method: X-ray } \\
\text { diffraction } \\
\text { Amino acids: } 266\end{array}$ & $\begin{array}{l}\text { Xenopus oocytes- } \\
5 \mathrm{ng} \text { cRNA } \\
\mathrm{P}_{\mathrm{f}}: 10 \times 10^{-3} \mathrm{~cm} / \mathrm{s} \text { (control } \\
0.67 \times 10^{-3} \mathrm{~cm} / \mathrm{s} \text { ) } \\
\mathrm{p}_{\mathrm{f}}: 5.0 \times 10^{-14} \mathrm{~cm}^{3} / \mathrm{s} \\
\text { — single channel } \\
\text { permeability }\end{array}$ & $\begin{array}{l}\text { Salivary, lacrimal } \\
\text { and sweat glands } \\
\text { Lung }\end{array}$ & $\begin{array}{l}\text { Sjögren's } \\
\text { syndrome }\end{array}$ & {$[7,32,47]$} \\
\hline AQP6 & $\begin{array}{l}\text { No structural data } \\
\text { available } \\
\text { UniProtKB-Q13520 } \\
\text { Species: Homo sapiens } \\
\text { Amino acids: } 282\end{array}$ & $\begin{array}{l}\text { Xenopus oocytes- } \\
5-10 \mathrm{ng} \text { cRNA } \\
\mathrm{P}_{\mathrm{f}}: 1.2 \times 10^{-3} \mathrm{~cm} / \mathrm{s} \\
\left(\text { control } 0.53 \times 10^{-3} \mathrm{~cm} / \mathrm{s}\right) \\
\left(93 \times 10^{-4} \mathrm{~cm} / \mathrm{s} \text { after }\right. \\
\text { activation with mercury) } \\
\text { No single channel data } \\
\text { available. }\end{array}$ & Collecting duct & Unknown & {$[48,49]$} \\
\hline
\end{tabular}


Table 1. Cont.

\begin{tabular}{|c|c|c|c|c|c|}
\hline AQP & $\begin{array}{l}\text { Structural } \\
\text { Information } \\
\text { Available }\end{array}$ & $\begin{array}{l}\text { Water Permeability } \\
\text { (Glycerol Permeability Is } \\
\text { Also Given for } \\
\text { Aquaglyceroporins) }\end{array}$ & $\begin{array}{l}\text { Main Locations in } \\
\text { Humans }\end{array}$ & Disease States & References \\
\hline AQP7 & $\begin{array}{l}\text { No structural data } \\
\text { available } \\
\text { UniProtKB-O14520 } \\
\text { Species: Homo sapiens } \\
\text { Amino acids: } 342\end{array}$ & $\begin{array}{l}\text { Xenopus oocytes- } \\
5 \text { ng cRNA } \\
\mathrm{P}_{\mathrm{f}}: 18.6 \times 10^{-3} \mathrm{~cm} / \mathrm{s} \\
\left(\text { control } 1.7 \times 10^{-3} \mathrm{~cm} / \mathrm{s}\right) \\
\mathrm{P}_{\text {gly }}: 18.9 \times 10^{-6} \mathrm{~cm} / \mathrm{s} \\
\text { No single channel data } \\
\text { available }\end{array}$ & $\begin{array}{l}\text { Adipocytes } \\
\text { Testis } \\
\text { Proximal kidney } \\
\text { tubule }\end{array}$ & $\begin{array}{l}\text { Adipocyte } \\
\text { hypertrophy }\end{array}$ & {$[4,8]$} \\
\hline AQP8 & $\begin{array}{l}\text { No structural data } \\
\text { available } \\
\text { UniProtKB-O94778 } \\
\text { Species: Homo sapiens } \\
\text { Amino acids: } 261\end{array}$ & $\begin{array}{l}\text { Xenopus oocytes- } \\
10 \text { ng cRNA } \\
\mathrm{P}_{\mathrm{f}}: 22 \times 10^{-3} \mathrm{~cm} / \mathrm{s} \text { (control } \\
0.8 \times 10^{-3} \mathrm{~cm} / \mathrm{s} \text { ) } \\
\mathrm{p}_{\mathrm{f}}: 8.2 \times 10^{-14} \mathrm{~cm}^{3} / \mathrm{s} \\
\text { - single channel } \\
\text { permeability }\end{array}$ & $\begin{array}{l}\text { Pancreas } \\
\text { Testis }\end{array}$ & Unknown & {$[44,50]$} \\
\hline AQP9 & $\begin{array}{l}\text { No structural data } \\
\text { available } \\
\text { UniProtKB-O43315 } \\
\text { Species: Homo sapiens } \\
\text { Amino acids: } 295\end{array}$ & $\begin{array}{l}\text { Xenopus oocytes- } \\
10 \text { ng cRNA } \\
\mathrm{P}_{\mathrm{f}}: 12.3 \times 10^{-3} \mathrm{~cm} / \mathrm{s} \\
\left(\text { control } 1.8 \times 10^{-3} \mathrm{~cm} / \mathrm{s}\right) \\
\mathrm{P}_{\text {gly }}: \sim 10 \times 10^{-6} \mathrm{~cm} / \mathrm{s} \\
\left(\text { controls: } \mathrm{H}_{2} \mathrm{O} 0 \mathrm{~cm} / \mathrm{s},\right. \\
\left.\text { AQP } 42.5 \times 10^{-6} \mathrm{~cm} / \mathrm{s}\right) \\
\text { No single channel data } \\
\text { available }\end{array}$ & $\begin{array}{l}\text { Hepatocytes } \\
\text { Osteoclasts } \\
\text { Astrocytes } \\
\text { Leukocytes }\end{array}$ & Osteoporosis & {$[43,51]$} \\
\hline AQP10 & $\begin{array}{l}\text { PDB ref: } 6 \mathrm{~F} 7 \mathrm{H} \\
\text { Resolution: } 2.3 \AA \\
\text { Species: Homo sapiens } \\
\text { Method: X-ray } \\
\text { diffraction } \\
\text { Amino acids: } 301\end{array}$ & $\begin{array}{l}\text { Xenopus oocytes- } \\
10 \text { ng cRNA } \\
\mathrm{P}_{\mathrm{f}}: \sim 0.05 \times 10^{-3} \mathrm{~cm} / \mathrm{s} \\
\text { (controls: negative control } \\
\sim 0.02 \times 10^{-3} \mathrm{~cm} / \mathrm{s}, \text { AQP8 } \\
\sim 0.2 \times 10^{-3} \mathrm{~cm} / \mathrm{s} \\
\text { No single channel data } \\
\text { available }\end{array}$ & $\begin{array}{l}\text { Intestinal epithelial } \\
\text { cells } \\
\text { Adipocytes }\end{array}$ & Unknown & {$[44,52]$} \\
\hline AQP11 & $\begin{array}{l}\text { No structural data } \\
\text { available } \\
\text { UniProtKB-Q8NBQ7 } \\
\text { Species: Homo sapiens } \\
\text { Amino acids: } 271\end{array}$ & $\begin{array}{l}\text { Spodoptera frugiperda-Sf9 } \\
\text { membrane vesicles } \\
\text { containing } 1 \mu \mathrm{g} \text { mouse } \\
\text { AQP11 protein } \\
\mathrm{P}_{\mathrm{f}}: 29.8 \times 10^{-3} \mathrm{~cm} / \mathrm{s} \\
(\text { controls: negative control } \\
8.2 \times 10^{-3} \mathrm{~cm} / \mathrm{s} \text {, } \\
246.1 \times 10^{-3} \mathrm{~cm} / \mathrm{s} \text { human } \\
\mathrm{AQP} 1,197.7 \times 10^{-3} \mathrm{~cm} / \mathrm{s} \\
\text { His-rat AQP4) } \\
\text { No single channel data } \\
\text { available }\end{array}$ & $\begin{array}{l}\text { Testis } \\
\text { Thymus } \\
\text { Kidney } \\
\text { Liver }\end{array}$ & Polycystic kidneys & {$[44,53]$} \\
\hline AQP12 & $\begin{array}{l}\text { No structural data } \\
\text { available } \\
\text { AQP12A } \\
\text { UniProtKB-Q8IXF9 } \\
\text { AQP12B } \\
\text { UniProtKB-A6NM10 } \\
\text { Species: Homo sapiens } \\
\text { Amino acids: } 295\end{array}$ & $\begin{array}{l}\text { Pancreatic rough } \\
\text { endoplasmic reticulum } \\
\text { vesicles-600 } \mu \mathrm{g} \text { total RNA } \\
\mathrm{P}_{\mathrm{f}}: 13.0 \times 10^{-3} \mathrm{~cm} / \mathrm{s} \\
\left.\text { (control } 15.1 \times 10^{-3} \mathrm{~cm} / \mathrm{s}\right) \\
\text { non-significant difference } \\
\text { No single channel data } \\
\text { available }\end{array}$ & $\begin{array}{l}\text { Pancreatic acinar } \\
\text { cells }\end{array}$ & Unknown & {$[54,55]$} \\
\hline
\end{tabular}

\section{Aquaporin Function}

AQP channels facilitate the movement of water and small uncharged solutes across membranes down a concentration gradient. As such, they are implicated in a myriad of diseases and AQP modulators are thought to be promising therapeutic targets for new drug development $[8,14]$. In some cases, compounds that modify the transcription and translation of AQPs may also be beneficial such as modifying AQP7 expression as a treatment for obesity [14]. Most of the information currently known about AQPs pertains to AQPs 1, 2, 3, and 4, which are the focus of this review. Table 1 shows the currently-known structural and functional features of AQP family members. AQP4 appears to have the highest known water permeability of the AQPs and its role as the major AQP within the central nervous system (CNS) supports this, as tight control is required to ensure optimal conditions for CNS 
function. The lowest permeabilities are seen in AQP0 and AQP6. The main function of AQP0 as the major intrinsic protein (MIP) in the eye lens (where it has a structural and adhesive function) means that it does not require a high water permeability. AQP6 is an intracellular AQP, but its main function is not yet known.

\section{1. $A Q P 1$}

AQP1 was first identified in red blood cells and is linked to pathologies such as cancer, the inability to concentrate urine, and altered pain sensation [37,40,56]. Expression of AQP1 in some tumor types is correlated with increased angiogenesis, invasion, metastasis, and growth [3,57]. Aggressive melanomas were shown to have higher expression of AQP1. Silencing of the AQP1 gene in a mouse melanoma xenograft model, reduced angiogenesis and metastasis [1]. In addition to this, it was found that matrix metalloproteinase (MMP) 2 was downregulated upon AQP1 knockdown although it was not determined which of AQP1 or MMP2 was important in mediating this effect [1]. AQP1 is also found in the endothelial cells of the lungs and epithelial cells of bile ducts as well as the kidney tubules and in the epithelia of the proximal convoluted tubule and the loop of Henle [10,47]. AQP1-deficient humans are unable to concentrate their urine beyond $450 \mathrm{mOsm}$ compared to the more normal $1000 \mathrm{mOsm}$ and above [8,58]. They are also prone to fluid accumulation in the lungs [47]. Modulating AQP1 may therefore lead to treatments that can aid conditions of excess fluid such as heart failure and cirrhosis $[3,10,14]$. Another role of AQP1 is pain perception; its deletion can cause a reduction of pain from inflammation or cold providing a possible basis for analgesia [3]. There is also evidence to show AQP1 in the choroid plexus where cerebrospinal fluid is produced [47].

\section{2. $A Q P 2$}

AQP2 is found in the kidneys, specifically within the cells of the collecting duct. Its regulation is one of the best-studied examples of hormone-mediated AQP translocation; following vasopressin (anti-diuretic hormone) release, AQP2-containing vesicles translocate to the plasma membrane facilitating water reabsorption [8,59]. Vasopressin binds to $V_{2}$ receptors of the principal cells in the renal collecting ducts, activating cAMP and protein kinase (PK) A, which phosphorylates Ser-256 and causes the exocytosis of AQP2-containing vesicles [25,60]. Central diabetes insipidus is the lack of vasopressin and its key symptoms are polyuria with an inability to concentrate urine [61]. Nephrogenic diabetes insipidus (NDI) is usually caused by a problem with the vasopressin receptor on collecting duct cells and is often linked to the AQP2 gene expression [61]. There are also cases of inherited NDI which can be caused by the same vasopressin receptor mutations but also mutations in the AQP2 gene; 19 such mutations have been identified $[42,60]$. Acquired diabetes insipidus is seen in cases such as long term lithium therapy where AQP2 subcellular localization can become dysregulated resulting in reduced surface localization and therefore loss of AQP2 function [47]. When vasopressin is secreted inappropriately, high levels of water retention and hyponatremia occur [61]. This is also seen in conditions such as congestive heart failure, where there is increased water retention due to an upregulation of vasopressin, and consequently AQP2 expression and translocation to the plasma membrane $[60,62]$. The exact mechanism by which AQP2 is recycled in the principal collecting duct cells is not yet known, however clathrin-coated pits are thought to have a role in this process [63].

\section{3. $A Q P 3$}

AQP3 is an aquaglyceroporin that allows the transport of glycerol in addition to water [8]. It is found in the epithelia of renal collecting ducts, urinary tract, digestive tract, and respiratory tract [47]. It is also found in the skin and aids skin hydration [13]. The overexpression of AQP3 is linked to skin malignancies such as melanomas $[64,65]$. AQP3 knock-out (KO) mice have been shown to be resistant to tumor formation in skin cancer models through reduced glycerol transport, resulting in lower ATP formation and reduced cell proliferation $[3,14,57,64]$. AQP3 has also been shown to transport hydrogen peroxide and this function aids NF- $\mathrm{kB}$ signaling. AQP3 $\mathrm{KO}$ mice had reduced $\mathrm{H}_{2} \mathrm{O}_{2}$ levels, impaired 
NF- $\mathrm{KB}$ activation and a reduced induction of psoriasis [66]. In addition to this, AQP3 has roles within the normal function of bacterial phagocytosis by macrophages and the trafficking of $\mathrm{T}$ cells $[3,67,68]$.

\subsection{AQP4}

AQP4 is the main water channel expressed in the CNS and is found at highest concentration in astrocyte end-feet, which together with blood vessels form the blood-brain barrier (BBB) [13,69]. AQP4 expression is increased in cerebral edema and ischemia. This has been shown to be correlated with the release of inflammatory cytokines [3,13,70,71]. AQP4 is also thought to aid the migration of astrocytes when neuronal injury occurs and glial scars form [72]. AQP4 has been shown to have a link with seizures where the regulation of cell volume by water flow can reduce susceptibility to seizures [73]. For the potassium channel, Kir 4.1, to be active, water flow through AQP4 is required $[1,9,71,74,75]$. During trauma or ischemia to the brain, there is a state of hypoxia which is then followed by a failure in $\mathrm{Na}^{+}, \mathrm{K}^{+}$, and $\mathrm{Cl}^{-}$pumps in the plasma membrane, causing dysregulation of osmolality [56,76-78]. This results in an increased intracranial pressure (ICP) and cerebral edema due to water flow, primarily into astrocytes during the cytotoxic phase of cerebral edema [70]. Limited therapeutic options are currently available to control cerebral edema. They are restricted to the administration of hyperosmotic solutions (such as mannitol, glycerol, and sodium chloride), hypothermia, or ultimately a surgical intervention to remove part of the skull to alleviate the uncontrolled rise in ICP $[70,79,80]$. AQP4 inhibition may be beneficial in cytotoxic edema as AQP4 KO mice were protected from cytotoxic edema. $[3,13,14,56,70,81]$. Vasogenic edema occurs due the movement of water and plasma proteins across a leaky BBB $[9,76]$. In models of vasogenic edema, however, AQP4 KO resulted in worse outcomes, due to an inability to remove excess water from brain tissue $[3,9,56,70]$. Any inhibition of AQP4 function, therefore needs to be acute.

Neuromyelitis optica (NMO) is an autoimmune condition where the CNS is affected by inflammation and demyelination [82]. It is symptomatically similar to multiple sclerosis (MS), but there are some key differences including the fact that some treatments for MS can exacerbate NMO [82]. Most patients with NMO have autoantibodies that target AQP4 in astrocytes and cause complement- and cell-mediated cytotoxicity [83]. The usual treatment for NMO involves steroids and other immunosuppressants such as azathioprine and mycophenolate [82].

\section{5. $A Q P S 0,5-12$}

AQP0, also known as MIP, was first identified within the lens. Its role is not only as a water channel (it has a low permeability compared to other family members, Table 1) but also to maintain the transparency and structure of the lens [35]. Mutations in the genes for AQP0 were found to result in congenital cataracts $[35,84]$.

AQP5 was first found within the submandibular glands and is now known to have a role within many secretory glands including salivary, lacrimal, and sweat glands [85]. Binding of acetylcholine to muscarinic M3 receptors is thought to induce the translocation of AQP5 vesicles to the cell surface membrane and problems with this process have been shown to be linked to conditions such as Sjögren's syndrome $[32,86,87]$.

AQP6 is an intracellular water channel found in vesicles and its water permeability is low [48], as shown in Table 1. These vesicles also contain $\mathrm{H}^{+}$-ATPase and AQP6 has been found to become more active at low $\mathrm{pH}$ suggesting that the role of AQP6 is in acid secretion [27,84].

AQP7, an aquaglyceroporin, is found in adipocytes and is thought to have a role in fat metabolism aiding degradation of triglycerides in fasting states [8]. AQP7 KO mice are seen to have higher levels of fat than wild type controls and this is thought to be a therapeutic target for obesity [13]. However, in the case of an individual with a homozygous nonfunctional AQP7 mutation, body mass index, cholesterol, and glucose levels were all normal, with only a reduced increase in glycerol levels during exercise compared to controls [88]. 
AQP8 has been identified in the brain, small intestine, testis, and the salivary glands [49]. Its function was disputed, but it is now known that AQP8 transports ammonia, as well as water, and that the transport of ammonia may be its primary function, maintaining acid-base equilibrium [30].

AQP9, an aquaglyceroporin, is found in hepatocytes and its function is thought to be significant during periods of exercise or prolonged fasting affecting glucose production [85]. It is found in osteoclasts and is thought to have a role in osteoporosis [89]. It is also found in astrocytes and leukocytes $[43,49]$. AQP9 and AQP7 are also known to mediate the uptake of arsenic compounds, which are used in some cancer treatments [44].

Little is known about the remaining AQPs. AQP10, an aquaglyceroporin, is found in intestinal epithelial cells and in adipocytes [43,47,90]. AQP11 is an intracellular aquaporin but its function remains unclear [44]. AQP11 contains a cysteine residue instead of an alanine in its first NPA motif and in the second motif, it has a leucine instead of an arginine [91]. It is found to be expressed in the testis, brain, kidneys, and liver [43]. AQP11 KO mice have been found to die soon after birth due to polycystic kidney disease [92]. This is thought to be due to AQP11 being required for correct glycosylation of polycystin-1 and -2 [93]. AQP12 is expressed in pancreatic acinar cells and in AQP12 KO models, those that develop pancreatitis develop a much more severe pathology $[54,55]$.

\section{Aquaporin Assays}

Water permeability can be assayed in various ways. Measuring volume change due to osmotic gradients is one indirect approach. Epithelial assays are based on using epithelial tissues placed on permeable supports and adding solutes to cause the fluid in a capillary tube to move. Transepithelial flux is measured via this change and fluorescent dyes can be used to evaluate permeability $[94,95]$. Transepithelial permeability results from water flow that has occurred both cellularly and paracellularly, whereas water flux through AQPs occurs only cellularly, which is a limitation of this as an approach to deducing AQP function.

Osmotic swelling techniques are by far the most common methods used for assaying volume changes and Xenopus oocytes are often used as they have a very low intrinsic water permeability [96]. Osmotic gradients are used and oocytes expressing AQPs change volume when these gradients are altered [97]. While the use of Xenopus oocytes is very common, there is substantial variability between oocyte preparations, meaning data may vary between laboratories even using the same materials [94,98].

Microscopy techniques are also used to measure permeability via a fluorophore that is taken up by cells. Esterases within the cell produce the active fluorophore and the rate of change of fluorophore concentration can then be detected using a plate-reader or fluorescence microscope after an osmotic gradient has been applied [99]. The limitation of this technique is that the fluorescence is relative to the dimensions of the cell monolayer where thinner cells produce a larger relative change in fluorescence than cell-lines that have a thicker monolayer. This can affect reproducibility in the same cell-line if confluence is varied between assays. It is also dependent on the amount of fluorophore that is taken up by the cells, which can sometimes be pumped out, producing variability in the data [100].

Stopped-flow spectroscopy involves the use of suspensions of cells, vesicles, or proteoliposomes which are mixed with solutes to produce a change in volume. The difference in light-scattering after this volume change can then be used to calculate the volume change [99]. Limitations of stopped-flow spectroscopy techniques include the dead time and mixing ability of the instrument used [101,102].

Computational methods involve the use of high-resolution structures and molecular dynamics simulations, which can provide new insights into AQP structure and function at atomic resolution. However, high-quality structures are not always available and simulations can sometimes produce data that are different from experimental data $[94,103]$. A summary of these techniques is shown in Table 2. 
Table 2. Various assay methods used in the measurement of AQP function and the validation of AQP inhibitors. Their benefits and limitations are shown.

\begin{tabular}{|c|c|c|c|c|}
\hline Assay Type & Assay Principle & Benefits & Limitations & References \\
\hline Epithelial & $\begin{array}{l}\text { Epithelial cells are placed on } \\
\text { supports, solutes are added } \\
\text { and transepithelial flux is } \\
\text { measured by the height of the } \\
\text { fluid in capillary tubes }\end{array}$ & $\begin{array}{l}\text { Assists AQP identification } \\
\text { and characterization in } \\
\text { tissues } \\
\text { Individual membrane } \\
\text { permeability is calculated }\end{array}$ & $\begin{array}{l}\text { Not very robust } \\
\text { Measures paracellular as } \\
\text { well as cellular water flow }\end{array}$ & {$[94,95]$} \\
\hline Osmotic Swelling & $\begin{array}{l}\text { Osmotic gradients are used to } \\
\text { cause flux of solutes and water } \\
\text { in cells } \\
\text { endogenously-expressing or } \\
\text { transfected with AQP genes; } \\
\text { cell volume changes are } \\
\text { measured }\end{array}$ & $\begin{array}{l}\text { Well-established technique } \\
\text { Oocytes have low intrinsic } \\
\text { water permeability } \\
\text { Other cells can be used } \\
\text { Inward and outward } \\
\text { gradients possible }\end{array}$ & $\begin{array}{l}\text { Preparation techniques } \\
\text { vary causing } \\
\text { discrepancies in results } \\
\text { between laboratories } \\
\text { Not very reproducible } \\
\text { Variability between } \\
\text { oocytes }\end{array}$ & {$[94,96,98]$} \\
\hline Microscopy & $\begin{array}{l}\text { Most often fluorescent dyes are } \\
\text { used that permeate the plasma } \\
\text { membrane and are cleaved by } \\
\text { esterases. As osmotic shock } \\
\text { occurs, the fluorescence is } \\
\text { altered, which is measured and } \\
\text { used to calculate cell volume } \\
\text { changes }\end{array}$ & $\begin{array}{l}\text { Linear relationship } \\
\text { produced between } \\
\text { fluorophore and cell volume } \\
\text { changes } \\
\text { More accurate than } \\
\text { counterparts } \\
\text { Very sensitive } \\
\text { Robust }\end{array}$ & $\begin{array}{l}\text { Thickness of cell-line } \\
\text { monolayer can produce } \\
\text { variability in results } \\
\text { Fluorophore may not } \\
\text { always stay within the } \\
\text { cell depending on } \\
\text { cell-line }\end{array}$ & {$[94,99,104]$} \\
\hline $\begin{array}{l}\text { Stopped-Flow } \\
\text { Spectroscopy }\end{array}$ & $\begin{array}{l}\text { Suspensions of cells or vesicles } \\
\text { are mixed with various osmotic } \\
\text { solutions and flux of water } \\
\text { causes volume changes, which } \\
\text { result in altered light scattering. } \\
\text { The linear relationship between } \\
\text { optical properties and cell } \\
\text { volume allows permeability to } \\
\text { be calculated; alternatively } \\
\text { fluorophores can be used. }\end{array}$ & $\begin{array}{l}\text { Fast kinetics measured } \\
\text { Can use cells, vesicles and } \\
\text { proteoliposomes } \\
\text { Linear relationship between } \\
\text { optical properties and } \\
\text { volume changes }\end{array}$ & $\begin{array}{l}\text { Variability in dead time } \\
\text { and mixing ability can } \\
\text { cause problems with } \\
\text { reproducibility }\end{array}$ & {$[94,99,101]$} \\
\hline $\begin{array}{l}\text { Computational } \\
\text { Methods }\end{array}$ & $\begin{array}{l}\text { High resolution atomic } \\
\text { structures of AQPs are used } \\
\text { and molecular dynamics } \\
\text { simulations allow in silico } \\
\text { measurement of water } \\
\text { permeability }\end{array}$ & $\begin{array}{l}\text { Provides new insights into } \\
\text { AQP structure and function }\end{array}$ & $\begin{array}{l}\text { High-quality structures } \\
\text { not always available } \\
\text { May disagree with } \\
\text { experimental data }\end{array}$ & {$[94,103]$} \\
\hline
\end{tabular}

\section{Aquaporin Inhibitors}

Most of the molecules that are currently under investigation as AQP inhibitors target AQPs 1, 2, 3 , or 4 . There are many patents, clinical trials, and studies on AQP up-regulators, modulators, and inhibitors. For the purposes of this review, only AQP inhibitors are considered (Table 3).

Table 3. Currently-available AQP inhibitors, their structures, the AQPs they inhibit (species are highlighted as $\mathrm{h} —$ human, $\mathrm{m}$ - mouse, and $\mathrm{r}$-rat) and the conditions under which they were assayed.

\begin{tabular}{clll}
\hline \multicolumn{1}{c}{ Inhibitor } & Conditions & $\begin{array}{l}\text { AQPs } \\
\text { Inhibited }\end{array}$ & Structure \\
\hline Tetraethyl- ammonium & $\begin{array}{l}\text { Xenopus oocytes } \\
100 \mu \mathrm{M}\end{array}$ & hAQP1 & {$[105,106]$} \\
\hline
\end{tabular}


Table 3. Cont.

\begin{tabular}{|c|c|c|c|c|}
\hline Inhibitor & Conditions & $\begin{array}{l}\text { AQPs } \\
\text { Inhibited }\end{array}$ & Structure & References \\
\hline Phloretin & $\begin{array}{l}\text { Xenopus oocytes } \\
0.1 \mathrm{mM} \\
\text { Proteoliposomes } \\
0.5 \mathrm{mM}\end{array}$ & $\begin{array}{l}\text { rAQP9 } \\
\text { hAQP3 }\end{array}$ & & {$[107,108]$} \\
\hline Mercury chloride & $\begin{array}{l}\text { Xenopus oocytes } \\
1 \mathrm{mM}\end{array}$ & hAQP1 & & {$[96,109]$} \\
\hline AuPhen & $\begin{array}{l}\text { Erythrocytes } \\
50 \mu \mathrm{M} \\
\text { Adipocytes } \\
15 \mu \mathrm{M}\end{array}$ & $\begin{array}{l}\text { hAQP3 } \\
\text { hAQP7 }\end{array}$ & & {$[110,111]$} \\
\hline Silver nitrate & $\begin{array}{l}\text { Erythrocytes } \\
10 \mu \mathrm{M}\end{array}$ & hAQP3 & & [112] \\
\hline Copper sulfate & $\begin{array}{l}\text { Swan } 71 \text { cells } \\
100 \mu \mathrm{M}\end{array}$ & hAQP3 & $\mathrm{Cu}^{++}$ & [113] \\
\hline Nickel chloride & $\begin{array}{l}\text { Human bronchial } \\
\text { epithelium cells } \\
1 \mathrm{mM}\end{array}$ & hAQP3 & & [114] \\
\hline Furosemide & $\begin{array}{l}\text { Xenopus oocytes } \\
10 \mu \mathrm{M}\end{array}$ & hAQP1 & & [115] \\
\hline Bumetanide & $\begin{array}{l}\text { Xenopus oocytes } \\
100 \mu \mathrm{M}\end{array}$ & rAQP4 & & [116] \\
\hline $\begin{array}{l}N \text {-(5-Sulfamoyl- } \\
\text { 1,3,4-thiadiazol-2-yl) } \\
\text { acetamide }\end{array}$ & $\begin{array}{l}\text { Xenopus oocytes } \\
20 \mu \mathrm{M}\end{array}$ & hAQP4-M23 & & [117] \\
\hline IMD-0354 & $\begin{array}{l}\text { Mice } \\
0.76 \mathrm{mg} / \mathrm{kg}\end{array}$ & mAQP4-M23 & & [118] \\
\hline
\end{tabular}


Table 3. Cont.

\begin{tabular}{|c|c|c|c|c|}
\hline Inhibitor & Conditions & $\begin{array}{l}\text { AQPs } \\
\text { Inhibited }\end{array}$ & Structure & References \\
\hline Acetazolamide & $\begin{array}{l}\text { HEK293 cells } \\
10 \mu \mathrm{M}\end{array}$ & $\begin{array}{l}\text { rAQP1 } \\
\text { rAQP4 }\end{array}$ & & [119] \\
\hline TGN-020 & $\begin{array}{l}\text { C57/BL6 male } \\
\text { mice } \\
200 \mathrm{mg} / \mathrm{kg} \mathrm{(23-28} \\
\text { g) }\end{array}$ & mAQP4 & & [81] \\
\hline Topiramate & $\begin{array}{l}\text { Xenopus oocytes } \\
20 \mu \mathrm{M}\end{array}$ & rAQP4-M23 & & [120] \\
\hline DFP00173 & $\begin{array}{l}\text { Human } \\
\text { erythrocytes } \\
25 \mu \mathrm{M}\end{array}$ & hAQP3 & & [121] \\
\hline Z433927330 & $\begin{array}{l}\text { Human } \\
\text { erythrocytes } \\
25 \mu \mathrm{M}\end{array}$ & mAQP7 & & [121] \\
\hline
\end{tabular}

Several molecules have been suggested as inhibitors of various AQPs over the past few years. Of these, most are small molecules (Table 3). The similarity found between AQPs and ion channels has caused interest in ion channel modulators as possible AQP inhibitors [43]. Arylsulfonamides such as acetazolamide are molecules that have attracted attention as potential AQP inhibitors [122]. Anti-epileptic drugs (AEDs) have also been suggested to have an AQP modulating function [70]. However, they have yet to be proven as definitive AQP inhibitors. A novel molecule named TGN-020 has shown great promise very recently as an inhibitor in mouse models [81]. Micro RNA (miRNA) and small interfering RNA (siRNA) have also been used to modulate AQPs [70]. Mercury chloride binds to a pore-lining cysteine residue found on several (but not all) AQPs and blocks the channel [3]. Mercury and its compounds is known to be toxic due to their non-specificity which causes many off-target effects [11]. Other heavy metal compounds (such as silver and gold compounds) have been investigated as inhibitors, but the challenge is finding a molecule with a side-effect profile that is tolerable. Currently-known inhibitors are discussed by type in the sections below.

\subsection{Small Molecule Inhibitors}

Tetraethylammonium (TEA) is a small molecule inhibitor that was first tested due to perceived similarities between AQPs and ion channels. Using human AQP1 expressed in Xenopus oocytes, a maximum single dose of $10 \mathrm{mM}$ TEA caused a reduction in water permeability of $33 \%$ [105]. Another study using $4 \mu \mathrm{M}$ and $100 \mu \mathrm{M}$ TEA showed an inhibition of $44 \%$ for Xenopus oocytes expressing AQP1, with no differences at the two concentrations; TEA also inhibited AQP2 and AQP4, with maximal 
inhibition of $40 \%$ and $57 \%$, respectively, at $100 \mu \mathrm{M}$ TEA [123]. Further testing of TEA in Xenopus oocytes or in native AQP1-expressing erythrocytes has failed to show inhibition $[3,124]$. TEA is thought to act by binding to a tyrosine residue located on the extracellular end of transmembrane helix 5 [123].

Acetazolamide is a carbonic anhydrase inhibitor used in glaucoma to reduce aqueous humor production and hence intraocular pressure [125]. It has been shown to be a reversible inhibitor of AQP1 and AQP4 (Table 3). It has inhibitory effects on Xenopus oocytes expressing human AQP4 in a dose-dependent manner with maximal inhibition of $85 \%$ at the highest dose of $20 \mu \mathrm{M}$ [126]. A reduction in the water permeability of rat AQP4 (assayed in proteoliposomes) to $46 \%$ was observed at a maximum dose of $1.25 \mathrm{mM}$ acetazolamide [127]. In HEK293 cells expressing rat AQP1, there was a 39\% reduction in water permeability with $100 \mu \mathrm{M}$ acetazolamide compared to untreated rat AQP1 (using GFP fluorescence to measure swelling) [119]. However, acetazolamide appears to be unable to inhibit endogenous AQPs in human cells [10,124].

Anti-epileptic drugs (AEDs) have also been suggested as possible AQP inhibitors [120]. Their anti-epileptic action has been hypothesized take place through modulation of AQPs. Many AEDs such as topiramate, zonisamide, and lamotrigine are known to have a similar inhibitory effect to acetazolamide on carbonic anhydrase enzyme as well as an in silico predicted binding site on AQP4 that is similar to that hypothesized for acetazolamide [120]. AEDs had an inhibitory effect on AQP4 in Xenopus oocytes [120], however, this could not be reproduced in rat thyroid epithelial cells [122]. AEDs are thought to possibly have an inhibitory effect on AQP1, AQP4, and AQP5 [128]. However due to their unconfirmed mechanisms of action and relatively non-specific action, there is no conclusive evidence showing that AEDs are effective and safe AQP inhibitors [10,122].

TGN-020 was shown in mouse models to significantly reduce AQP4-mediated edema following ischemia, but the molecule was administered before injury [81]. There was an approximately $10 \%$ reduction in brain volume [81]. Therapeutic administration must necessarily occur after a stroke, although a prophylactic treatment could be considered if the side effect profile of TGN-020 was acceptable. TGN-020 has since been tested on the same middle cerebral artery occlusion (MCAO) model and administered post-injury in mice. In a study using mouse models at a dose of $100 \mathrm{mg} / \mathrm{kg}$, TGN-020 was administered 15 minutes post-ischemic injury and treated animals had better motor scores and less AQP4 expression around blood vessels when compared to untreated controls [129]. The half-maximal inhibitory concentration ( $\mathrm{IC}_{50}$ ) of TGN-020 was $3 \mu \mathrm{M}$ in Xenopus oocytes expressing human AQP4, but there is no evidence to show that TGN-020 is AQP4-specific [130].

Phloretin is a small molecule that acts as a non-specific aquaglyceroporin inhibitor. It has also been shown to inhibit the urea transporter, UT-A1, found in the kidney [131]. It has been speculated that the same mechanism underpinning urea inhibition is responsible for inhibition of the aquaglyceroporins, AQP3 and AQP9 [107,132]. Then $100 \mu \mathrm{M}$ of phloretin was used to inhibit AQP9 expressed in Xenopus oocytes, resulting in an $86 \%$ inhibition [107]. AQP3 glycerol permeability in proteoliposomes was inhibited by $500 \mu \mathrm{M}$ phloretin, producing $83 \%$ inhibition. Phloretin had no effect on control proteoliposomes which had a $\mathrm{P}_{\text {gly }}$ of $\sim 2.8 \times 10^{-6} \mathrm{~cm} / \mathrm{s}$ [108].

A recent study identified new inhibitors of the aquaglyceroporins, AQP3 and AQP7. The compound DFP00173 was able to inhibit the glycerol permeability of human erythrocytes with an $\mathrm{IC}_{50}$ of $\sim 0.2 \mu \mathrm{M}$. Compound Z433927330 reduced glycerol permeability with an $\mathrm{IC}_{50}$ of $\sim 0.6 \mu \mathrm{M}$. In a Chinese hamster ovary cell-line, compound DFP00173 was able to inhibit mouse AQP3 with an $\mathrm{IC}_{50}$ of $\sim 0.1 \mu \mathrm{M}$ and was selective for AQP3 over AQP7 and AQP9. Compound Z433927330 was able to inhibit mouse AQP7 in the same cell-line with an $\mathrm{IC}_{50}$ of $\sim 0.2 \mu \mathrm{M}$ and with selectivity for AQP7 over $\mathrm{AQP} 3$ and $\mathrm{AQP} 9 ; \mathrm{IC}_{50}$ s for this compound for mouse AQP3 and AQP9 were $\sim 0.7 \mu \mathrm{M}$ and $\sim 1.1 \mu \mathrm{M}$, respectively [121].

\subsection{Heavy Metal Ion Inhibitors}

Heavy metal compounds have been used in cytotoxic treatments for many years, with the use of the platinum compound cisplatin being notable in cancer therapy. Many AQPs have been correlated 
with cancers, their presence influencing disease severity, increased local invasion, and the occurrence of metastasis [57]. AQP1 overexpression has been identified in brain, breast, lung, renal, cervical, ovarian, and colorectal cancers [133]. AQP3 overexpression has been found in skin, stomach, renal, liver, colorectal, lung, and cervical cancers [134]. AQP3 is highly expressed in skin carcinoma cells. The uptake of glycerol through AQP3 is thought to aid the growth of these cancer cells [57]. AQP4 overexpression is found in brain, lung, and thyroid cancers [135]. AQP5 overexpression has been found in breast, cervical, colorectal, liver, lung, pancreatic, ovarian, and esophageal cancers [136]. AQP7 and AQP8 overexpression are found in thyroid and cervical cancer, respectively [133]. AQP9 overexpression has been found in brain, liver, and ovarian cancers [136].

Nickel chloride has been shown to inhibit AQP3 overexpressed in human bronchial epithelium cells. Water permeability was reduced to approximately $60 \%$ in cells treated with $1 \mathrm{mM} \mathrm{NiCl} 2$ compared to non-transfected control cells [114]. Mutational studies showed that the extracellular loop residues, Trp-128, Ser-152, and His-241, were all required for the observed inhibitory effect, but that further studies are required to confirm similar effects in other AQP3-expressing tissues such as the kidney [114]. Copper ions also inhibit AQP3 function and attempts to reduce the toxicity of copper compounds have been addressed by using nanoparticles for delivery [57]. Copper sulfate has been identified as an AQP3 inhibitor at $100 \mu \mathrm{M}$ [113]. It is believed that copper ions act by binding the same three residues on the extracellular loops as nickel ions [137]. This inhibition mechanism is different from that of mercury ions, which bind to Cys-40 in AQP3 [137,138]. Copper compounds have been shown to specifically inhibit AQP3 and not AQP4, AQP5, or AQP1 [137], while other AQPs remain to be tested. Gold-based compounds have also been used as AQP3 inhibitors and have been shown to be effective. AQP3 is found in erythrocytes, alongside AQP1, however its role is mostly for glycerol rather than both water and glycerol permeability [110]. Erythrocytes showed a 90\% decrease in glycerol permeability following treatment with $50 \mu \mathrm{M}$ AuPhen. The binding of this gold compound is thought to be via Cys-40 and inhibition can be almost completely reversed by the addition of the reducing agent, 2-mercaptoethanol [110]. AuPhen and other Au(III) compounds such as Auterpy were also compared with copper and platinum compounds as AQP3 inhibitors [111,139]. Due to their effective inhibition of glycerol transport in AQP3, they were tested on AQP7, another aquaglyceroporin. Initial results have demonstrated that $15 \mu \mathrm{M}$ AuPhen inhibited water and glycerol transport through AQP7 [111]: there was a reduction in water permeability (63\%) as well as glycerol permeability $(79 \%)$. Adipocytes overexpressing hAQP7 were used and permeability was measured using loading with $5 \mu \mathrm{M}$ of calcein-AM and hyperosmotic shock. In silico docking studies suggest that Auphen binds AQP7 through an interaction with Met-47 [140]. Silver has also been used as a possible AQP inhibitor and is found to produce a rapid and irreversible inhibition of AQP1 in erythrocytes [112]. It has been shown to be a much more potent inhibitor of AQP1 in erythrocytes than mercury, [112]. Silver nitrate and silver sulfadiazine were tested as inhibitors to prevent shrinking of human erythrocytes in hyperosmotic solutions. A dose-response curve was used to calculate an $\mathrm{IC}_{50}$ of $3.9 \mu \mathrm{m}$ and $1.24 \mu \mathrm{m}$ and a $60 \%$ and $75 \%$ inhibition for silver nitrate and silver sulfadiazine, respectively. Gold and silver are thought to bind to sulfhydryl groups on cysteine residues of AQPs, but the complete mechanisms are not yet understood [110-112].

\section{Antibody Treatments}

An anti-AQP4 monoclonal antibody was developed as a potential treatment for NMO. "Aquaporumab" competitively binds to AQP4 in astrocytes and displaces AQP4-IgG, reducing NMO lesions in mouse models $[82,83]$. This is yet to be tested in humans, although in vivo studies have been promising [141].

\section{Patents and Clinical Trials}

A search of the European Patent Office archive in February 2019 returned 484 AQP-related patents or patent applications. These documents protect various techniques and methods such as 
AQP upregulation and modulation, detection methods, mRNA expression, as well as siRNA silencing techniques. Approximately 40 of these patents are for inhibitors of AQPs or NMO treatments.

US patent 2008/0194513 A1 identifies the proliferation of blood vessels within the eyes as a factor in sight loss in several ocular conditions. Interfering RNAs were therefore used to silence AQP4 mRNA expression in order to reduce ocular neovascularization. Administration of siRNA at 1-10 $\mathrm{nM}$ provided over 70\% inhibition of AQP4 expression in Madin-Darby canine kidney (MDCK) cells transfected with human AQP4 compared to controls [142]. A similar patent was filed by the same inventors using similar techniques for the inhibition of AQP1 expression for ocular conditions [143].

US patent 7,659,312 B2 identifies various AQP4 inhibitors to be used in cerebral edema and other water-related disorders. Twenty-one compounds are described that are similar in structure to the loop diuretics, furosemide, and bumetanide. A total of 15 compounds had inhibitory effects on AQP4 when tested in Xenopus oocytes transfected with AQP4-M23. $20 \mu \mathrm{M}$ inhibitor compounds were used and experiments were completed twice. Aryl sulphonamide-like compounds and bi-aryl compounds were identified as inhibitors. Docking energies were also analyzed using AQP4 monomers built from electron diffraction structures; compounds with higher inhibition often had better docking energies.

Phenylbenzamide-based compounds are patented inhibitors of AQP2 and AQP4 for the treatment of AQP-related conditions such as edema, ischemic stroke, epilepsy, and meningitis. Phenylbenzamides such as niclosamide, a compound usually used for treatment of helminth infections, is known to have an inhibitory effect on NF-kB and IKK- $\beta$. The compound IMD-0354 was used to inhibit IKK- $\beta$ in myocardial ischemia models [144]. Compound 3 has a similar structure to IMD-0354 but the two trifluromethyl groups are replaced by chloride. Compound 3 is claimed to be an inhibitor of AQP2, AQP4-M1, and AQP4-M23 with over 60\% inhibition. It was at very poor inhibitor of AQP1 and AQP5. Compound 1 (IMD-0354) inhibited cerebral edema formation in a murine water toxicity model. Treatment with $0.76 \mathrm{mg} / \mathrm{kg}$ produced an $11.2 \%$ reduction, while $7.6 \mathrm{mg} / \mathrm{kg}$ showed a $15.9 \%$ reduction in edema. Following MCAO in mice, there was a $29.4 \%$ increase in survival $24 \mathrm{~h}$ post-injury [118]. A subsequent patent described prodrug salts of these compounds [145].

Ghrelin is a 28 amino acid peptide that is secreted by gastric mucosa cells and is a hormone that regulates hunger. It is known to also have other anti-inflammatory properties thought to be protective in neuronal injury [146]. Traumatic brain injury (TBI) causes acute, elevated ICP and brain damage. Repeated mild brain injuries ( $\mathrm{mBI}$ ), such as concussions, can cause long-term injury to the brain and increased risk of neurodegeneration with aging. Treatments for TBI and $\mathrm{mBI}$ are very limited. Administration of ghrelin reduced the levels of reactive oxygen species in neurons and volume loss in mice post-injury [147]. The administration of ghrelin at doses 1.5-1000 times native levels provided therapeutic effects lasting from 30 minutes up to $24 \mathrm{~h}$. Ghrelin was also able to reduce oxidative bursts post $\mathrm{mBI}$ [148]. Ghrelin has been shown to reduce levels of brain water after acute hypoxia in rats, as well as the permeability of blood vessels. It is thought to do this through reduction in TNF- $\alpha$ levels together with other anti-inflammatory effects on IL1, IL6, and NF-KB [149]. In another study, levels of AQP4, serum S100B and vascular permeability were quantified to show disruption of the BBB post-TBI in mice. Treatment with ghrelin was able to reduce these levels and help prevent BBB damage post-TBI [150].

A possible NMO treatment centers on a peptide corresponding to AQP4 loop C. T cells reactive to this peptide from AQP4 -/- mice produced a pathological response reminiscent of NMO when injected into AQP4 +/+ mice. T cells are found in NMO lesions and are thought to be required for the production of anti-AQP4 IgG. It was noted that immunosuppression therapy would be required before treatment takes place [151].

US patent 2015/0224108 A1 presents techniques to create prodrugs and derivatives of the loop diuretics, bumetanide and furosemide, as AQP inhibitors and to aid their administration to the site of action [152].

The use of phloretin as an AQP9 inhibitor was shown to reduce osteoclast levels. This inhibition would aid treatment in conditions such as osteoporosis, where excessive bone resorption takes place. 
AQP9 expression is higher in osteoclasts than other cells; $50 \mu \mathrm{M}$ phloretin inhibited AQP9 expression, causing a reduction in size and number of osteoclasts but not their precursors [153].

A search of the US National Library of Medicines Clinical Trials archive in February 2019 returned 61 clinical trials involving AQP-based treatments. Several of these trials examine urinary AQP2 levels and the conditions under which they are altered. Several trials also examine NMO, MS, and the therapeutic use of AQP4-IgGs. A search of the University Hospital Medical Information Network (UMIN) - Clinical Trials Registry in February 2019 returned two current clinical trials taking place using anti-AQP4 IgGs. There are currently no clinical trials taking place in the UK using AQP inhibitors or anti-AQP4 IgGs according to the UK Clinical Trials Gateway.

\section{Discussion}

Finding inhibitors for AQP water channels has been considerably more challenging than first thought. The identification of molecules that inhibit water transport through specific AQP isoforms is not a simple proposition for drug discovery on account of the high level of structural conservation within the AQP family (Table 1). The small diameter of all AQP-pores together with the chemical properties of the pore-lining amino acid side-chains mean that hydrophilic compounds are unlikely to enter and block them.

No definitive, small molecule AQP inhibitors have been identified to date that could be used therapeutically. Heavy metal compounds are certainly effective AQP inhibitors, but their non-specificity and toxicity substantially limit their therapeutic potential. Using liposomes to administer heavy metal compounds would reduce off-target effects, but more research is required. The most promising AQP inhibitor with clinical potential to date is TGN-020, which has not yet shown any side effects in vivo, but is yet to be tested in human clinical trials. Notably, antibodies used for NMO treatment have no effect on water permeability. There is a clear need for AQP modulators, particularly in conditions such as TBI where, in the early stages, AQP4 inhibition is required to manage cytotoxic edema but, thereafter, upregulation of AQP4 would aid clearance of vasogenic edema.

The lack of reliable in vitro phenotypic assays suitable for screening and validating the pharmacological regulation of AQP function (Table 2), means that pharmaceutical companies have been unable to meet the challenge of developing small molecules that block the AQP pore. For example, molecules discovered using Xenopus oocytes consistently fail to show efficacy in mammalian cells and vice versa. Screening programs for AQP inhibitors should therefore include multiple assays that allow more robust and reproducible readouts.

\section{Conclusions}

AQPs are expressed ubiquitously and have implications in myriad human diseases. The progress of identifying AQP inhibitors has been slow and as research continues, AQPs are increasingly implicated in more diseases, highlighting the clear and urgent need for AQP modulators. More research is needed to find effective AQP inhibitors. Current screening processes are extremely variable. Approaches to standardize assays would be beneficial in identifying promising molecules for future study.

Funding: This work was supported by a UK Biotechnology and Biological Sciences Research Council International Partnering Award (BB/P025927/1) to PK, ACC, and RMB. MA is supported by a studentship co-funded by Aston University and the UK Engineering and Physical Sciences Research Council (EP/R512889/1) to RMB. PK is the recipient of an Aston University $50^{\text {th }}$ Anniversary Prize Fellowship. MMS was supported by HCED grant number GD-13-13 (M. Salman).

Conflicts of Interest: The authors declare no conflict of interest. 


\section{Abbreviations}

\begin{tabular}{|c|c|}
\hline $\mathrm{AQP}$ & aquaporin \\
\hline NPA & Asn-Pro-Ala \\
\hline$\AA$ & Ångstrom \\
\hline CNS & central nervous system \\
\hline MIP & major intrinsic protein \\
\hline RNA & ribonucleic acid \\
\hline cRNA & complementary ribonucleic acid \\
\hline MMP & matrix metalloproteinase \\
\hline cAMP & cyclic adenosine monophosphate \\
\hline PKA & protein kinase $\mathrm{A}$ \\
\hline NDI & nephrogenic diabetes insipidus \\
\hline $\mathrm{KO}$ & knock-out \\
\hline BBB & blood-brain barrier \\
\hline $\mathrm{ICP}$ & intracranial pressure \\
\hline $\mathrm{NMO}$ & neuromyelitis optica \\
\hline MS & multiple sclerosis \\
\hline AEDs & anti-epileptic drugs \\
\hline miRNA & micro ribonucleic acid \\
\hline siRNA & small interfering ribonucleic acid \\
\hline TEA & tetraethylammonium \\
\hline$\mu \mathrm{M}$ & micromolar \\
\hline HEK293 & human embryonic kidney 293 \\
\hline MCAO & middle cerebral artery occlusion \\
\hline IC50 & half maximal inhibitory concentration \\
\hline $\mathrm{NiCl}_{2}$ & nickel chloride \\
\hline $\mathrm{mM}$ & millimolar \\
\hline GFP & green fluorescent protein \\
\hline hAQP & human aquaporin \\
\hline calcein-AM & calcein acetoxymethyl \\
\hline $\mathrm{AgNO}_{3}$ & silver nitrate \\
\hline AgSul & silver sulfadiazine \\
\hline $\operatorname{IgG}$ & immunoglobulin G \\
\hline mRNA & messenger ribonucleic acid \\
\hline qPCR & quantitative polymerase chain reaction \\
\hline ELISA & enzyme-linked immunosorbent assay \\
\hline $\mathrm{nM}$ & nanomolar \\
\hline NF- $k B$ & nuclear factor kappa-light-chain-enhancer of activate B cells \\
\hline IKK- $\beta$ & inhibitor of nuclear factor kappa-B \\
\hline $24 \mathrm{~h}$ & 24 hours \\
\hline TBI & traumatic brain injury \\
\hline $\mathrm{mBI}$ & mild brain injury \\
\hline TNF- $\alpha$ & tumor necrosis factor alpha \\
\hline IL1 & interleukin 1 \\
\hline IL6 & interleukin 6 \\
\hline UMIN & University Hospital Medical Information Network \\
\hline
\end{tabular}

\section{References}

1. Simone, L.; Gargano, C.D.; Pisani, F.; Cibelli, A.; Mola, M.G.; Frigeri, A.; Svelto, M.; Nicchia, G.P. Aquaporin-1 inhibition reduces metastatic formation in a mouse model of melanoma. J. Cell. Mol. Med. 2018, 22, 904-912. [CrossRef] [PubMed]

2. Qiu, J.; Zhang, Y.Z.; Chen, H.; Guo, Z. MicroRNA-488 inhibits proliferation, invasion and EMT in osteosarcoma cell lines by targeting aquaporin 3. Int. J. Oncol. 2018, 53, 1493-1504. [CrossRef] 
3. Verkman, A.S.; Anderson, M.O.; Papadopoulos, M.C. Aquaporins: Important but elusive drug targets. Nat. Rev. Drug Discov. 2014, 13, 259. [CrossRef]

4. Ishibashi, K.; Kuwahara, M.; Gu, Y.; Kageyama, Y.; Tohsaka, A.; Suzuki, F.; Marumo, F.; Sasaki, S. Cloning and Functional Expression of a New Water Channel Abundantly Expressed in the Testis Permeable to Water, Glycerol, and Urea. J. Biol. Chem. 1997, 272, 20782-20786. [CrossRef]

5. Geyer, R.R.; Musa-Aziz, R.; Qin, X.; Boron, W.F. Relative CO2/NH3 selectivities of mammalian aquaporins 0-9. Am. J. Physiol.-Cell Physiol. 2013, 304, C985-C994. [CrossRef]

6. Litman, T.; Søgaard, R.; Zeuthen, T. Ammonia and Urea Permeability of Mammalian Aquaporins. In Aquaporins; Beitz, E., Ed.; Springer: Berlin/Heidelberg, Germany, 2009; pp. 327-358. [CrossRef]

7. Yang, B.; Verkman, A.S. Water and Glycerol Permeabilities of Aquaporins 1-5 and MIP Determined Quantitatively by Expression of Epitope-tagged Constructs inXenopus Oocytes. J. Biol. Chem. 1997, 272, 16140-16146. [CrossRef]

8. Agre, P.; Kozono, D. Aquaporin water channels: Molecular mechanisms for human diseases1. FEBS Lett. 2003, 555, 72-78. [CrossRef]

9. Verkman, A.S.; Smith, A.J.; Phuan, P.-w.; Tradtrantip, L.; Anderson, M.O. The aquaporin-4 water channel as a potential drug target in neurological disorders. Expert Opin. Ther. Targets 2017, 21, 1161-1170. [CrossRef]

10. Yang, B.; Kim, J.K.; Verkman, A.S. Comparative efficacy of $\mathrm{HgCl} 2$ with candidate aquaporin-1 inhibitors DMSO, gold, TEA+ and acetazolamide. FEBS Lett. 2006, 580, 6679-6684. [CrossRef]

11. Castle, N.A. Aquaporins as targets for drug discovery. Drug Discov. Today 2005, 10, 485-493. [CrossRef]

12. Eriksson, U.K.; Fischer, G.; Friemann, R.; Enkavi, G.; Tajkhorshid, E.; Neutze, R. Subangstrom resolution X-ray structure details aquaporin-water interactions. Science 2013, 340, 1346-1349. [CrossRef] [PubMed]

13. Papadopoulos, M.C.; Verkman, A.S. Aquaporin-4 and brain edema. Pediatr. Nephrol. 2007, 22, 778-784. [CrossRef]

14. Tradtrantip, L.; Jin, B.-J.; Yao, X.; Anderson, M.O.; Verkman, A.S. Aquaporin-Targeted Therapeutics: State-of-the-Field. Adv. Exp. Med. Biol. 2017, 969, 239-250.

15. Janosi, L.; Ceccarelli, M. The gating mechanism of the human aquaporin 5 revealed by molecular dynamics simulations. PLoS ONE 2013, 8, e59897. [CrossRef] [PubMed]

16. Kitchen, P.; Conner, M.T.; Bill, R.M.; Conner, A.C. Structural Determinants of Oligomerization of the Aquaporin-4 Channel. J. Biol. Chem. 2016, 291, 6858-6871. [CrossRef]

17. Verkman, A.S.; Mitra, A.K. Structure and function of aquaporin water channels. Am. J. Physiol.-Ren. Physiol. 2000, 278, F13-F28. [CrossRef] [PubMed]

18. Gonen, T.; Walz, T. The structure of aquaporins. Quart. Rev. Biophys. 2006, 39, 361-396. [CrossRef] [PubMed]

19. Yool, A.J.; Weinstein, A.M. New Roles for Old Holes: Ion Channel Function in Aquaporin-1. Physiology 2002, 17, 68-72. [CrossRef]

20. Yool, A.J.; Stamer, W.D.; Regan, J.W. Forskolin Stimulation of Water and Cation Permeability in Aquaporin1 Water Channels. Science 1996, 273, 1216-1218. [CrossRef]

21. Agre, P.; Lee, M.D.; Devidas, S.; Guggino, W.B. Aquaporins and Ion Conductance. Science 1997, 275, 1490-1492. [CrossRef]

22. Anthony, T.L.; Brooks, H.L.; Boassa, D.; Leonov, S.; Yanochko, G.M.; Regan, J.W.; Yool, A.J. Cloned Human Aquaporin-1 Is a Cyclic GMP-Gated Ion Channel. Mol. Pharmacol. 2000, 57, 576-588. [CrossRef] [PubMed]

23. Wang, Y.; Cohen, J.; Boron, W.F.; Schulten, K.; Tajkhorshid, E. Exploring gas permeability of cellular membranes and membrane channels with molecular dynamics. J. Struct. Biol. 2007, 157, 534-544. [CrossRef] [PubMed]

24. Endeward, V.; Arias-Hidalgo, M.; Al-Samir, S.; Gros, G. $\mathrm{CO}_{2}$ Permeability of Biological Membranes and Role of $\mathrm{CO}_{2}$ Channels. Membranes 2017, 7, 61. [CrossRef]

25. Gomes, D.; Agasse, A.; Thiébaud, P.; Delrot, S.; Gerós, H.; Chaumont, F. Aquaporins are multifunctional water and solute transporters highly divergent in living organisms. Biochim. Biophys. Acta (BBA) Biomembr. 2009, 1788, 1213-1228. [CrossRef] [PubMed]

26. Ikeda, M.; Beitz, E.; Kozono, D.; Guggino, W.B.; Agre, P.; Yasui, M. Characterization of Aquaporin-6 as a Nitrate Channel in Mammalian Cells: REQUIREMENT OF PORE-LINING RESIDUE THREONINE 63. J. Biol. Chem. 2002, 277, 39873-39879. [CrossRef] [PubMed]

27. Yasui, M.; Kwon, T.-H.; Knepper, M.A.; Nielsen, S.; Agre, P. Aquaporin-6: An intracellular vesicle water channel protein in renal epithelia. Proc. Natl. Acad. Sci. USA 1999, 96, 5808-5813. [CrossRef] [PubMed] 
28. Hazama, A.; Kozono, D.; Guggino, W.B.; Agre, P.; Yasui, M. Ion Permeation of AQP6 Water Channel Protein: SINGLE-CHANNEL RECORDINGS AFTER Hg2+ACTIVATION. J. Biol. Chem. 2002, 277, 29224-29230. [CrossRef]

29. Krane, C.M.; Goldstein, D.L. Comparative functional analysis of aquaporins/glyceroporins in mammals and anurans. Mamm. Genome 2007, 18, 452-462. [CrossRef]

30. Saparov, S.M.; Liu, K.; Agre, P.; Pohl, P. Fast and Selective Ammonia Transport by Aquaporin-8. J. Biol. Chem. 2007, 282, 5296-5301. [CrossRef]

31. Soria, L.R.; Fanelli, E.; Altamura, N.; Svelto, M.; Marinelli, R.A.; Calamita, G. Aquaporin-8-facilitated mitochondrial ammonia transport. Biochem. Biophys. Res. Commun. 2010, 393, 217-221. [CrossRef]

32. Horsefield, R.; Nordén, K.; Fellert, M.; Backmark, A.; Törnroth-Horsefield, S.; Terwisscha van Scheltinga, A.C.; Kvassman, J.; Kjellbom, P.; Johanson, U.; Neutze, R. High-resolution x-ray structure of human aquaporin 5. Proc. Natl. Acad. Sci. USA 2008, 105, 13327-13332. [CrossRef]

33. Kitchen, P.; Day, R.E.; Salman, M.M.; Conner, M.T.; Bill, R.M.; Conner, A.C. Beyond water homeostasis: Diverse functional roles of mammalian aquaporins. Biochim. Biophys. Acta (BBA) 2015, 1850, 2410-2421. [CrossRef] [PubMed]

34. Han, B.-G.; Guliaev, A.B.; Walian, P.J.; Jap, B.K. Water Transport in AQP0 Aquaporin: Molecular Dynamics Studies. J. Mol. Biol. 2006, 360, 285-296. [CrossRef] [PubMed]

35. Chepelinsky, A.B. Structural Function of MIP/Aquaporin 0 in the Eye Lens; Genetic Defects Lead to Congenital Inherited Cataracts. In Aquaporins; Beitz, E., Ed.; Springer: Berlin/Heidelberg, Germany, 2009; pp. 265-297. [CrossRef]

36. Harries, W.E.; Akhavan, D.; Miercke, L.J.; Khademi, S.; Stroud, R.M. The channel architecture of aquaporin 0 at a 2.2-A resolution. Proc. Natl. Acad. Sci. USA 2004, 101, 14045-14050. [CrossRef] [PubMed]

37. Nielsen, S.; Smith, B.L.; Christensen, E.I.; Agre, P. Distribution of the aquaporin CHIP in secretory and resorptive epithelia and capillary endothelia. Proc. Natl. Acad. Sci. USA 1993, 90, 7275-7279. [CrossRef]

38. Agre, P. Aquaporin water channels (Nobel Lecture). Angew. Chem. Int. Ed. Engl. 2004, 43, 4278-4290. [CrossRef]

39. Noda, Y.; Sohara, E.; Ohta, E.; Sasaki, S. Aquaporins in kidney pathophysiology. Nat. Rev. Nephrol. 2010, 6, 168-178. [CrossRef]

40. Murata, K.; Mitsuoka, K.; Hirai, T.; Walz, T.; Agre, P.; Heymann, J.B.; Engel, A.; Fujiyoshi, Y. Structural determinants of water permeation through aquaporin-1. Nature 2000, 407, 599. [CrossRef]

41. Frick, A.; Eriksson, U.K.; de Mattia, F.; Öberg, F.; Hedfalk, K.; Neutze, R.; de Grip, W.J.; Deen, P.M.T.; Törnroth-Horsefield, S. X-ray structure of human aquaporin 2 and its implications for nephrogenic diabetes insipidus and trafficking. Proc. Natl. Acad. Sci. USA 2014, 111, 6305-6310. [CrossRef] [PubMed]

42. Calvanese, L.; D'Auria, G.; Vangone, A.; Falcigno, L.; Oliva, R. Structural Basis for Mutations of Human Aquaporins Associated to Genetic Diseases. Int. J. Mol. Sci. 2018, 19, 1577. [CrossRef] [PubMed]

43. Jeyaseelan, K.; Sepramaniam, S.; Armugam, A.; Wintour, E.M. Aquaporins: A promising target for drug development. Expert Opin. Ther. Targets 2006, 10, 889-909. [CrossRef] [PubMed]

44. Ishibashi, K.; Hara, S.; Kondo, S. Aquaporin water channels in mammals. Clin. Exp. Nephrol. 2009, 13, 107-117. [CrossRef]

45. Soler, D.C.; Young, A.E.; Griffith, A.D.; Fu, P.f.; Cooper, K.D.; McCormick, T.S.; Popkin, D.L. Overexpression of AQP3 and AQP10 in the skin exacerbates psoriasiform acanthosis. Exp. Dermatol. 2017, 26, 949-951. [CrossRef]

46. Ho, J.D.; Yeh, R.; Sandstrom, A.; Chorny, I.; Harries, W.E.C.; Robbins, R.A.; Miercke, L.J.W.; Stroud, R.M. Crystal structure of human aquaporin 4 at $1.8 \AA$ and its mechanism of conductance. Proc. Natl. Acad. Sci. USA 2009, 106, 7437-7442. [CrossRef] [PubMed]

47. Takata, K.; Matsuzaki, T.; Tajika, Y. Aquaporins: Water channel proteins of the cell membrane. Prog. Histochem. Cytochem. 2004, 39, 1-83. [CrossRef]

48. Yasui, M.; Hazama, A.; Kwon, T.-H.; Nielsen, S.; Guggino, W.B.; Agre, P. Rapid gating and anion permeability of an intracellular aquaporin. Nature 1999, 402, 184. [CrossRef] [PubMed]

49. Ishibashi, K.; Sasaki, S. Aquaporin water channels in mammals. Clin. Exp. Nephrol. 1997, 1, $247-253$. [CrossRef] 
50. Ma, T.; Yang, B.; Verkman, A.S. Cloning of a Novel Water and Urea-Permeable Aquaporin from Mouse Expressed Strongly in Colon, Placenta, Liver, and Heart. Biochem. Biophys. Res. Commun. 1997, 240, 324-328. [CrossRef]

51. Ishibashi, K.; Kuwahara, M.; Gu, Y.; Tanaka, Y.; Marumo, F.; Sasaki, S. Cloning and Functional Expression of a New Aquaporin (AQP9) Abundantly Expressed in the Peripheral Leukocytes Permeable to Water and Urea, but Not to Glycerol. Biochem. Biophys. Res. Commun. 1998, 244, 268-274. [CrossRef] [PubMed]

52. Hatakeyama, S.; Yoshida, Y.; Tani, T.; Koyama, Y.; Nihei, K.; Ohshiro, K.; Kamiie, J.-I.; Yaoita, E.; Suda, T.; Hatakeyama, K.; et al. Cloning of a New Aquaporin (AQP10) Abundantly Expressed in Duodenum and Jejunum. Biochem. Biophys. Res. Commun. 2001, 287, 814-819. [CrossRef] [PubMed]

53. Yakata, K.; Tani, K.; Fujiyoshi, Y. Water permeability and characterization of aquaporin-11. J. Struct. Biol. 2011, 174, 315-320. [CrossRef]

54. Ohta, E.; Itoh, T.; Nemoto, T.; Kumagai, J.; Ko, S.B.H.; Ishibashi, K.; Ohno, M.; Uchida, K.; Ohta, A.; Sohara, E.; et al. Pancreas-specific aquaporin 12 null mice showed increased susceptibility to caerulein-induced acute pancreatitis. Am. J. Physiol.-Cell Physiol. 2009, 297, C1368-C1378. [CrossRef] [PubMed]

55. Itoh, T.; Rai, T.; Kuwahara, M.; Ko, S.B.; Uchida, S.; Sasaki, S.; Ishibashi, K. Identification of a novel aquaporin, AQP12, expressed in pancreatic acinar cells. Biochem. Biophys. Res. Commun. 2005, 330, 832-838. [CrossRef]

56. Nakano, T.; Nishigami, C.; Irie, K.; Shigemori, Y.; Sano, K.; Yamashita, Y.; Myose, T.; Tominaga, K.; Matsuo, K.; Nakamura, Y.; et al. Goreisan Prevents Brain Edema after Cerebral Ischemic Stroke by Inhibiting Aquaporin 4 Upregulation in Mice. J. Stroke Cerebrovasc. Dis. 2018, 27, 758-763. [CrossRef] [PubMed]

57. Nave, M.; Castro, R.E.; Rodrigues, C.M.; Casini, A.; Soveral, G.; Gaspar, M.M. Nanoformulations of a potent copper-based aquaporin inhibitor with cytotoxic effect against cancer cells. Nanomedicine 2016, 11, 1817-1830. [CrossRef] [PubMed]

58. King, L.S.; Choi, M.; Fernandez, P.C.; Cartron, J.-P.; Agre, P. Defective Urinary Concentrating Ability Due to a Complete Deficiency of Aquaporin-1. N. Engl. J. Med. 2001, 345, 175-179. [CrossRef] [PubMed]

59. Kitchen, P.; Conner, A.C. Control of the Aquaporin- 4 Channel Water Permeability by Structural Dynamics of Aromatic/Arginine Selectivity Filter Residues. Biochemistry 2015, 54, 6753-6755. [CrossRef]

60. Deen, P.M.T.; van Balkom, B.W.M.; Kamsteeg, E.-J. Routing of the aquaporin-2 water channel in health and disease. Eur. J. Cell Biol. 2000, 79, 523-530. [CrossRef]

61. Judith Radin, M.; Yu, M.-J.; Stoedkilde, L.; Lance Miller, R.; Hoffert, J.D.; Frokiaer, J.; Pisitkun, T.; Knepper, M.A. Aquaporin-2 regulation in health and disease. Vet. Clin. Pathol. 2012, 41, 455-470. [CrossRef]

62. Schrier, R.W.; Cadnapaphornchai, M.A. Renal aquaporin water channels: From molecules to human disease. Prog. Biophys. Mol. Biol. 2003, 81, 117-131. [CrossRef]

63. Brown, D. The ins and outs of aquaporin-2 trafficking. Am. J. Physiol.-Ren. Physiol. 2003, 284, F893-F901. [CrossRef] [PubMed]

64. Hara-Chikuma, M.; Verkman, A.S. Prevention of Skin Tumorigenesis and Impairment of Epidermal Cell Proliferation by Targeted Aquaporin-3 Gene Disruption. Mol. Cell. Biol. 2008, 28, 326-332. [CrossRef]

65. Hara-Chikuma, M.; Verkman, A.S. Roles of Aquaporin-3 in the Epidermis. J. Investig. Dermatol. 2008, 128, 2145-2151. [CrossRef] [PubMed]

66. Hara-Chikuma, M.; Satooka, H.; Watanabe, S.; Honda, T.; Miyachi, Y.; Watanabe, T.; Verkman, A.S. Aquaporin-3-mediated hydrogen peroxide transport is required for NF- $\mathrm{BB}$ signalling in keratinocytes and development of psoriasis. Nat. Commun. 2015, 6, 7454. [CrossRef] [PubMed]

67. Zhu, N.; Feng, X.; He, C.; Gao, H.; Yang, L.; Ma, Q.; Guo, L.; Qiao, Y.; Yang, H.; Ma, T. Defective macrophage function in aquaporin-3 deficiency. Faseb J. 2011, 25, 4233-4239. [CrossRef]

68. Hara-Chikuma, M.; Chikuma, S.; Sugiyama, Y.; Kabashima, K.; Verkman, A.S.; Inoue, S.; Miyachi, Y. Chemokine-dependent $\mathrm{T}$ cell migration requires aquaporin-3-mediated hydrogen peroxide uptake. J. Exp. Med. 2012, 209, 1743-1752. [CrossRef]

69. Jullienne, A.; Fukuda, A.M.; Ichkova, A.; Nishiyama, N.; Aussudre, J.; Obenaus, A.; Badaut, J. Modulating the water channel AQP4 alters miRNA expression, astrocyte connectivity and water diffusion in the rodent brain. Sci. Rep. 2018, 8, 4186. [CrossRef]

70. Tang, G.; Yang, G.-Y. Aquaporin-4: A Potential Therapeutic Target for Cerebral Edema. Int. J. Mol. Sci. 2016, 17, 1413. [CrossRef] [PubMed] 
71. Wang, B.; Li, W.; Jin, H.; Nie, X.; Shen, H.; Li, E.; Wang, W. Curcumin attenuates chronic intermittent hypoxia-induced brain injuries by inhibiting AQP4 and p38 MAPK pathway. Respir. Physiol. Neurobiol. 2018, 255, 50-57. [CrossRef]

72. Verkman, A.S.; Phuan, P.-W.; Asavapanumas, N.; Tradtrantip, L. Biology of AQP4 and anti-AQP4 antibody: Therapeutic implications for NMO. Brain Pathol. 2013, 23, 684-695. [CrossRef] [PubMed]

73. Salman, M.M.; Sheilabi, M.A.; Bhattacharyya, D.; Kitchen, P.; Conner, A.C.; Bill, R.M.; Woodroofe, M.N.; Conner, M.T.; Princivalle, A.P. Transcriptome analysis suggests a role for the differential expression of cerebral aquaporins and the MAPK signalling pathway in human temporal lobe epilepsy. Eur. J. Neurosci. 2017, 46, 2121-2132. [CrossRef] [PubMed]

74. Binder, D.K.; Yao, X.; Zador, Z.; Sick, T.J.; Verkman, A.S.; Manley, G.T. Increased seizure duration and slowed potassium kinetics in mice lacking aquaporin-4 water channels. Glia 2006, 53, 631-636. [CrossRef] [PubMed]

75. Amiry-Moghaddam, M.; Williamson, A.; Palomba, M.; Eid, T.; de Lanerolle, N.C.; Nagelhus, E.A.; Adams, M.E.; Froehner, S.C.; Agre, P.; Ottersen, O.P. Delayed $\mathrm{K}^{+}$clearance associated with aquaporin-4 mislocalization: Phenotypic defects in brains of $\alpha$-syntrophin-null mice. Proc. Natl. Acad. Sci. USA 2003, 100, 13615-13620. [CrossRef] [PubMed]

76. Rosenberg, G.A. Ischemic brain edema. Prog. Cardiovasc. Dis. 1999, 42, 209-216. [CrossRef]

77. Simard, J.M.; Kent, T.A.; Chen, M.; Tarasov, K.V.; Gerzanich, V. Brain oedema in focal ischaemia: Molecular pathophysiology and theoretical implications. Lancet Neurol. 2007, 6, 258-268. [CrossRef]

78. Salman, M.M.; Kitchen, P.; Woodroofe, M.N.; Bill, R.M.; Conner, A.C.; Heath, P.R.; Conner, M.T. Transcriptome Analysis of Gene Expression Provides New Insights into the Effect of Mild Therapeutic Hypothermia on Primary Human Cortical Astrocytes Cultured under Hypoxia. Front. Cell. Neurosci. 2017, 11, 386. [CrossRef] [PubMed]

79. Yenari, M.A.; Han, H.S. Neuroprotective mechanisms of hypothermia in brain ischaemia. Nat. Rev. Neurosci. 2012, 13, 267. [CrossRef] [PubMed]

80. Salman, M.M.; Kitchen, P.; Woodroofe, M.N.; Brown, J.E.; Bill, R.M.; Conner, A.C.; Conner, M.T. Hypothermia increases aquaporin 4 (AQP4) plasma membrane abundance in human primary cortical astrocytes via a calcium/transient receptor potential vanilloid 4 (TRPV4)- and calmodulin-mediated mechanism. Eur. J. Neurosci. 2017, 46, 2542-2547. [CrossRef] [PubMed]

81. Igarashi, H.; Huber, V.J.; Tsujita, M.; Nakada, T. Pretreatment with a novel aquaporin 4 inhibitor, TGN-020, significantly reduces ischemic cerebral edema. Neurol. Sci. 2011, 32, 113-116. [CrossRef] [PubMed]

82. Papadopoulos, M.C.; Bennett, J.L.; Verkman, A.S. Treatment of neuromyelitis optica: State-of-the-art and emerging therapies. Nat. Rev. Neurol. 2014, 10, 493. [CrossRef]

83. Tradtrantip, L.; Zhang, H.; Saadoun, S.; Phuan, P.-W.; Lam, C.; Papadopoulos, M.C.; Bennett, J.L.; Verkman, A.S. Anti-Aquaporin-4 monoclonal antibody blocker therapy for neuromyelitis optica. Ann. Neurol. 2012, 71, 314-322. [CrossRef]

84. Agre, P.; King, L.S.; Yasui, M.; Guggino, W.B.; Ottersen, O.P.; Fujiyoshi, Y.; Engel, A.; Nielsen, S. Aquaporin water channels-from atomic structure to clinical medicine. J. Physiol. 2002, 542, 3-16. [CrossRef] [PubMed]

85. Day, R.E.; Kitchen, P.; Owen, D.S.; Bland, C.; Marshall, L.; Conner, A.C.; Bill, R.M.; Conner, M.T. Human aquaporins: Regulators of transcellular water flow. Biochim. Biophys. Acta (BBA) 2014, 1840, 1492-1506. [CrossRef] [PubMed]

86. Tada, J.; Sawa, T.; Yamanaka, N.; Shono, M.; Akamatsu, T.; Tsumura, K.; Parvin, M.N.; Kanamori, N.; Hosoi, K. Involvement of Vesicle-Cytoskeleton Interaction in AQP5 Trafficking in AQP5-Gene-Transfected HSG Cells. Biochem. Biophys. Res. Commun. 1999, 266, 443-447. [CrossRef]

87. Ishikawa, Y.; Eguchi, T.; Skowronski, M.T.; Ishida, H. Acetylcholine Acts on M3Muscarinic Receptors and Induces the Translocation of Aquaporin5 Water Channel via Cytosolic Ca2+Elevation in Rat Parotid Glands. Biochem. Biophys. Res. Commun. 1998, 245, 835-840. [CrossRef] [PubMed]

88. Kondo, H.; Shimomura, I.; Kishida, K.; Kuriyama, H.; Makino, Y.; Nishizawa, H.; Matsuda, M.; Maeda, N.; Nagaretani, H.; Kihara, S.; et al. Human aquaporin adipose (AQPap) gene. Eur. J. Biochem. 2002, 269, 1814-1826. [CrossRef]

89. Soveral, G.; Casini, A. Aquaporin modulators: A patent review (2010-2015). Expert Opin. Ther. Patents 2017, 27, 49-62. [CrossRef]

90. Laforenza, U.; Scaffino, M.F.; Gastaldi, G. Aquaporin-10 represents an alternative pathway for glycerol efflux from human adipocytes. PLoS ONE 2013, 8, e54474. [CrossRef] [PubMed] 
91. Gorelick, D.A.; Praetorius, J.; Tsunenari, T.; Nielsen, S.; Agre, P. Aquaporin-11: A channel protein lacking apparent transport function expressed in brain. BMC Biochem. 2006, 7, 14. [CrossRef]

92. Morishita, Y.; Matsuzaki, T.; Hara-chikuma, M.; Andoo, A.; Shimono, M.; Matsuki, A.; Kobayashi, K.; Ikeda, M.; Yamamoto, T.; Verkman, A.; et al. Disruption of aquaporin-11 produces polycystic kidneys following vacuolization of the proximal tubule. Mol. Cell. Biol. 2005, 25, 7770-7779. [CrossRef] [PubMed]

93. Inoue, Y.; Sohara, E.; Kobayashi, K.; Chiga, M.; Rai, T.; Ishibashi, K.; Horie, S.; Su, X.; Zhou, J.; Sasaki, S.; et al. Aberrant Glycosylation and Localization of Polycystin-1 Cause Polycystic Kidney in an AQP11 Knockout Model. J. Am. Soc. Nephrol. 2014, 25, 2789-2799. [CrossRef]

94. Madeira, A.; Moura, T.F.; Soveral, G. Detecting Aquaporin Function and Regulation. Front. Chem. 2016,4 , 3. [CrossRef] [PubMed]

95. Dorr, R.A.; Kierbel, A.; Vera, J.; Parisi, M. A new data-acquisition system for the measurement of the net water flux across epithelia. Comput. Methods Progr. Biomed. 1997, 53, 9-14. [CrossRef]

96. Preston, G.M.; Carroll, T.P.; Guggino, W.B.; Agre, P. Appearance of water channels in Xenopus oocytes expressing red cell CHIP28 protein. Science 1992, 256, 385-387. [CrossRef] [PubMed]

97. Kitchen, P.; Day, R.E.; Taylor, L.H.; Salman, M.M.; Bill, R.M.; Conner, M.T.; Conner, A.C. Identification and Molecular Mechanisms of the Rapid Tonicity-induced Relocalization of the Aquaporin 4 Channel. J. Biol. Chem. 2015, 290, 16873-16881. [CrossRef]

98. Patil, R.V.; Xu, S.; van Hoek, A.N.; Rusinko, A.; Feng, Z.; May, J.; Hellberg, M.; Sharif, N.A.; Wax, M.B.; Irigoyen, M.; et al. Rapid Identification of Novel Inhibitors of the Human Aquaporin-1 Water Channel. Chem. Biol. Drug Des. 2016, 87, 794-805. [CrossRef]

99. Mola, M.G.; Nicchia, G.P.; Svelto, M.; Spray, D.C.; Frigeri, A. Automated cell-based assay for screening of aquaporin inhibitors. Anal. Chem. 2009, 81, 8219-8229. [CrossRef]

100. Zelenina, M.; Brismar, H. Osmotic water permeability measurements using confocal laser scanning microscopy. Eur. Biophys. J. 2000, 29, 165-171. [CrossRef]

101. Dickson, P.N.; Margerum, D.W. Extension of accessible first-order rate constants and accurate dead-time determinations for stopped-flow spectroscopy. Anal. Chem. 1986, 58, 3153-3158. [CrossRef]

102. Keifer, P.A. Flow techniques in NMR spectroscopy. In Annual Reports on NMR Spectroscopy; Webb, G.A., Ed.; Academic Press: Cambridge, MA, USA, 2007; Volume 62, pp. 1-47.

103. Hub, J.S.; Grubmüller, H.; de Groot, B.L. Dynamics and Energetics of Permeation Through Aquaporins. What Do We Learn from Molecular Dynamics Simulations? In Aquaporins; Beitz, E., Ed.; Springer: Berlin/Heidelberg, Germany, 2009; pp. 57-76. [CrossRef]

104. Madeira, A.; Camps, M.; Zorzano, A.; Moura, T.F.; Soveral, G. Biophysical assessment of human aquaporin-7 as a water and glycerol channel in 3T3-L1 adipocytes. PLoS ONE 2013, 8, e83442. [CrossRef] [PubMed]

105. Brooks, H.L.; Regan, J.W.; Yool, A.J. Inhibition of Aquaporin-1 Water Permeability by Tetraethylammonium: Involvement of the Loop E Pore Region. Mol. Pharmacol. 2000, 57, 1021-1026.

106. Müller, E.M.; Hub, J.S.; Grubmüller, H.; de Groot, B.L. Is TEA an inhibitor for human Aquaporin-1? Pflug. Archiv Eur. J. Physiol. 2008, 456, 663-669. [CrossRef] [PubMed]

107. Tsukaguchi, H.; Shayakul, C.; Berger, U.V.; Mackenzie, B.; Devidas, S.; Guggino, W.B.; van Hoek, A.N.; Hediger, M.A. Molecular Characterization of a Broad Selectivity Neutral Solute Channel. J. Biol. Chem. 1998, 273, 24737-24743. [CrossRef] [PubMed]

108. Müller-Lucks, A.; Gena, P.; Frascaria, D.; Altamura, N.; Svelto, M.; Beitz, E.; Calamita, G. Preparative scale production and functional reconstitution of a human aquaglyceroporin (AQP3) using a cell free expression system. New Biotechnol. 2013, 30, 545-551. [CrossRef]

109. Preston, G.M.; Jung, J.S.; Guggino, W.B.; Agre, P. The mercury-sensitive residue at cysteine 189 in the CHIP28 water channel. J. Biol. Chem. 1993, 268, 17-20.

110. Martins, A.P.; Marrone, A.; Ciancetta, A.; Galán Cobo, A.; Echevarría, M.; Moura, T.F.; Re, N.; Casini, A.; Soveral, G. Targeting aquaporin function: Potent inhibition of aquaglyceroporin-3 by a gold-based compound. PLOS ONE 2012, 7, e37435. [CrossRef]

111. de Almeida, A.; Soveral, G.; Casini, A. Gold compounds as aquaporin inhibitors: New opportunities for therapy and imaging. MedChem Comm 2014, 5, 1444-1453. [CrossRef]

112. Niemietz, C.M.; Tyerman, S.D. New potent inhibitors of aquaporins: Silver and gold compounds inhibit aquaporins of plant and human origin. FEBS Lett. 2002, 531, 443-447. [CrossRef] 
113. Alejandra, R.; Natalia, S.; Alicia, E.D. The blocking of aquaporin-3 (AQP3) impairs extravillous trophoblast cell migration. Biochem. Biophys. Res. Commun. 2018, 499, 227-232. [CrossRef] [PubMed]

114. Zelenina, M.; Bondar, A.A.; Zelenin, S.; Aperia, A. Nickel and extracellular acidification inhibit the water permeability of human aquaporin-3 in lung epithelial cells. J. Biol. Chem. 2003, 278, 30037-30043. [CrossRef]

115. Ozu, M.; Dorr, R.A.; Teresa Politi, M.; Parisi, M.; Toriano, R. Water flux through human aquaporin 1: Inhibition by intracellular furosemide and maximal response with high osmotic gradients. Eur. Biophys. J. 2011, 40, 737-746. [CrossRef] [PubMed]

116. Migliati, E.; Meurice, N.; DuBois, P.; Fang, J.S.; Somasekharan, S.; Beckett, E.; Flynn, G.; Yool, A.J. Inhibition of aquaporin-1 and aquaporin- 4 water permeability by a derivative of the loop diuretic bumetanide acting at an internal pore-occluding binding site. Mol. Pharmacol. 2009, 76, 105-112. [CrossRef] [PubMed]

117. Tsutomu Nakada, V.H. Inhibitors of Aquaporin 4, Methods and Uses Thereof. U.S. Patent 7,659,312, 9 February 2010.

118. Pelletier, M.F.; Farr, G.W.; Mcguirk, P.R.; Hall, C.H.; Boron, W.F. Methods of Treating Cerebral Edema. U.S. Patent US9573885B2, 21 February 2017.

119. Gao, J.; Wang, X.; Chang, Y.; Zhang, J.; Song, Q.; Yu, H.; Li, X. Acetazolamide inhibits osmotic water permeability by interaction with aquaporin-1. Anal. Biochem. 2006, 350, 165-170. [CrossRef]

120. Huber, V.J.; Tsujita, M.; Kwee, I.L.; Nakada, T. Inhibition of Aquaporin 4 by antiepileptic drugs. Bioorg. Med. Chem. 2009, 17, 418-424. [CrossRef] [PubMed]

121. Sonntag, Y.; Gena, P.; Maggio, A.; Singh, T.; Artner, I.; Oklinski, M.K.; Johanson, U.; Kjellbom, P.; Nieland, J.D.; Nielsen, S.; et al. Identification and characterization of potent and selective aquaporin-3 and aquaporin-7 inhibitors. J. Biol. Chem. 2019. [CrossRef] [PubMed]

122. Yang, B.; Zhang, H.; Verkman, A.S. Lack of aquaporin-4 water transport inhibition by antiepileptics and arylsulfonamides. Bioorg. Med. Chem. 2008, 16, 7489-7493. [CrossRef]

123. Detmers, F.J.M.; de Groot, B.L.; Müller, E.M.; Hinton, A.; Konings, I.B.M.; Sze, M.; Flitsch, S.L.; Grubmüller, H.; Deen, P.M.T. Quaternary Ammonium Compounds as Water Channel Blockers: SPECIFICITY, POTENCY, AND SITE OF ACTION. J. Biol. Chem. 2006, 281, 14207-14214. [CrossRef]

124. Søgaard, R.; Zeuthen, T. Test of blockers of AQP1 water permeability by a high-resolution method: No effects of tetraethylammonium ions or acetazolamide. Pflüg. Arch. Eur. J. Physiol. 2008, 456, 285-292. [CrossRef] [PubMed]

125. Pastorekova, S.; Parkkila, S.; Pastorek, J.; Supuran, C.T. Review Article. J. Enzym. Inhib. Med. Chem. 2004, 19, 199-229. [CrossRef] [PubMed]

126. Huber, V.J.; Tsujita, M.; Yamazaki, M.; Sakimura, K.; Nakada, T. Identification of arylsulfonamides as Aquaporin 4 inhibitors. Bioorg. Med. Chem. Lett. 2007, 17, 1270-1273. [CrossRef] [PubMed]

127. Tanimura, Y.; Hiroaki, Y.; Fujiyoshi, Y. Acetazolamide reversibly inhibits water conduction by aquaporin-4. J. Struct. Biol. 2009, 166, 16-21. [CrossRef] [PubMed]

128. Shank, R.P.; Maryanoff, B.E. Molecular Pharmacodynamics, Clinical Therapeutics, and Pharmacokinetics of Topiramate. CNS Neurosci. Ther. 2008, 14, 120-142. [CrossRef] [PubMed]

129. Pirici, I.; Balsanu, T.A.; Bogdan, C.; Margaritescu, C.; Divan, T.; Vitalie, V.; Mogoanta, L.; Pirici, D.; Carare, R.O.; Muresanu, D.F. Inhibition of Aquaporin-4 Improves the Outcome of Ischaemic Stroke and Modulates Brain Paravascular Drainage Pathways. Int. J. Mol. Sci. 2017, 19, 46. [CrossRef] [PubMed]

130. Huber, V.J.; Tsujita, M.; Nakada, T. Aquaporins in drug discovery and pharmacotherapy. Mol. Asp. Med. 2012, 33, 691-703. [CrossRef]

131. Esteva-Font, C.; Phuan, P.-W.; Anderson, M.O.; Verkman, A.S. A Small Molecule Screen Identifies Selective Inhibitors of Urea Transporter UT-A. Chem. Biol. 2013, 20, 1235-1244. [CrossRef] [PubMed]

132. Ishibashi, K.; Sasaki, S.; Fushimi, K.; Uchida, S.; Kuwahara, M.; Saito, H.; Furukawa, T.; Nakajima, K.; Yamaguchi, Y.; Gojobori, T. Molecular cloning and expression of a member of the aquaporin family with permeability to glycerol and urea in addition to water expressed at the basolateral membrane of kidney collecting duct cells. Proc. Natl. Acad. Sci. USA 1994, 91, 6269-6273. [CrossRef] [PubMed]

133. Dajani, S.; Saripalli, A.; Sharma-Walia, N. Water transport proteins-aquaporins (AQPs) in cancer biology. Oncotarget 2018, 9, 36392-36405. [CrossRef]

134. Wang, J.; Feng, L.; Zhu, Z.; Zheng, M.; Wang, D.; Chen, Z.; Sun, H. Aquaporins as diagnostic and therapeutic targets in cancer: How far we are? J. Transl. Med. 2015, 13, 96. [CrossRef] 
135. Papadopoulos, M.C.; Saadoun, S. Key roles of aquaporins in tumor biology. Biochim. Biophys. Acta (BBA) Biomembr. 2015, 1848, 2576-2583. [CrossRef]

136. Aikman, B.; de Almeida, A.; Meier-Menches, S.M.; Casini, A. Aquaporins in cancer development: Opportunities for bioinorganic chemistry to contribute novel chemical probes and therapeutic agents. Metall. Integr. Biometal Sci. 2018, 10, 696-712. [CrossRef]

137. Zelenina, M.; Tritto, S.; Bondar, A.A.; Zelenin, S.; Aperia, A. Copper Inhibits the Water and Glycerol Permeability of Aquaporin-3. J. Biol. Chem. 2004, 279, 51939-51943. [CrossRef]

138. Spinello, A.; de Almeida, A.; Casini, A.; Barone, G. The inhibition of glycerol permeation through aquaglyceroporin-3 induced by mercury(II): A molecular dynamics study. J. Inorg. Biochem. 2016, 160, 78-84. [CrossRef] [PubMed]

139. Martins, A.P.; Ciancetta, A.; de Almeida, A.; Marrone, A.; Re, N.; Soveral, G.; Casini, A. Aquaporin Inhibition by Gold(III) Compounds: New Insights. ChemMedChem 2013, 8, 1086-1092. [CrossRef] [PubMed]

140. Madeira, A.; de Almeida, A.; de Graaf, C.; Camps, M.; Zorzano, A.; Moura, T.F.; Casini, A.; Soveral, G. A Gold Coordination Compound as a Chemical Probe to Unravel Aquaporin-7 Function. ChemBioChem 2014, 15, 1487-1494. [CrossRef] [PubMed]

141. Jha, R.M.; Kochanek, P.M.; Simard, J.M. Pathophysiology and treatment of cerebral edema in traumatic brain injury. Neuropharmacology 2019, 145, 230-246. [CrossRef] [PubMed]

142. Patil, R.V.; Chatterton, J.E.; Sharif, N.A.; Wax, M.B. RNAi-Mediated Inhibition of Aquaporin 4 for Treatment of Ocular Neovascularization. U.S. Patent US20080214486A1, 31 July 2008.

143. Chatterton, J.E.; Patil, R.V.; Sharif, N.A.; Clark, A.F.; Wax, M.B. RNAi-Mediated Inhibition of Aquaporin 1 for Treatment of Iop-Related Conditions. U.S. Patent US20080171719A1, 4 September 2008.

144. Haraguchi, G.; Suzuki, J.-I.; Kakuta, T.; Maejima, Y.; Onai, Y.; Isobe, M.; Itai, A.; Fukasawa, H.; Muto, S. Inhibition of I $\kappa$ B phosphorylation in cardiomyocytes attenuates myocardial ischemia/reperfusion injury. Cardiovasc. Res. 2004, 63, 51-59.

145. Pelletier, M.F.; Mcguirk, P.R.; Farr, G.W.; Zamboni, R.; Colucci, J.; Zaghdane, H. Prodrug Salts. U.S. Patent US9827253B2, 28 November 2017.

146. Baatar, D.; Patel, K.; Taub, D.D. The effects of ghrelin on inflammation and the immune system. Mol. Cell. Endocrinol. 2011, 340, 44-58. [CrossRef] [PubMed]

147. Lopez, N.E.; Lindsay, G.; Karina, L.R.; Mary, H.A.; Putnam, J.; Eliceiri, B.; Coimbra, R.; Bansal, V. Ghrelin decreases motor deficits after traumatic brain injury. J. Surg. Res. 2014, 187, 230-236. [CrossRef] [PubMed]

148. Bansal, V. Methods of Treating Mild Brain Injury. U.S. Patent US10105416B2, 23 October 2018.

149. Hossienzadeh, F.; Babri, S.; Alipour, M.R.; Ebrahimi, H.; Mohaddes, G. Effect of ghrelin on brain edema induced by acute and chronic systemic hypoxia. Neurosci. Lett. 2013, 534, 47-51. [CrossRef]

150. Lopez, N.E.; Krzyzaniak, M.J.; Blow, C.; Putnam, J.; Ortiz-Pomales, Y.; Hageny, A.-M.; Eliceiri, B.; Coimbra, R.; Bansal, V. Ghrelin Prevents Disruption of the Blood-Brain Barrier after Traumatic Brain Injury. J. Neurotrauma 2012, 29, 385-393. [CrossRef] [PubMed]

151. Levy, M. Highly Soluble Aquaporin-4 Extracellular Loop c Peptide Immunization for Treatment of Neuromyelitis Optica. U.S. Patent US20170080063A1, 23 March 2017.

152. Flynn, G.A.; Yool, A.J.; Migliati, E.R.; Ritter, L.S. Aquaporin Modulators and Methods of Using Them for the Treatment of Edema and Fluid Imbalance. U.S. Patent US20150224108A1, 13 August 2015.

153. Bar-shavit, Z.; Aharon, R. Modulation of Osteoclast Differentiation. U.S. Patent US20150065427A1, 5 March 2015.

(C) 2019 by the authors. Licensee MDPI, Basel, Switzerland. This article is an open access article distributed under the terms and conditions of the Creative Commons Attribution (CC BY) license (http:/ / creativecommons.org/licenses/by/4.0/). 